International Journal of Public Finance
E-ISSN: $2548-0499 \quad$ DOI: 10.30927/ijpf.319894
Vol./Cilt: 1 | Issue/Sayı: 2 | (2016), pp. 168-193
journal homepage: http://dergipark.gov.tr/ijpf

\title{
Vergi Denetiminde Risk Analizinin Yeri: Bazı Ülke Uygulamaları ve Türkiye İçin Bir Değerlendirme*
}

\author{
Place of Risk Analysis in Tax Audit: Some Country Practices and an \\ Evaluation for Turkey
}

Feride BAKAR $^{1}$

Adnan GERÇEK ${ }^{2}$

\section{ARTICLE INFO \\ Received: 25.02.2016 \\ Received in revised \\ form: 22.04.2016 \\ Accepted: 28.04.2016 \\ Available online: \\ 26.12.2016}

\section{JEL classification:}

K34, K33, H26

\section{Keywords:}

Tax Audit, Risk

Analysis, Effective-

ness of Tax Audit

\begin{abstract}
A B S T R A C T
The use of information technologies and risk analysis have become an important position in tax audit, as in all fields. Systems used in this area, are different in many ways and for this reason, making comparative study, evaluating best practices and its effects to results should be examined. In this study, development of risk analysis systems in Australia, United Kingdom, Austria, the USA and their place ensuring effectiveness of tax audit was investigated. Thus, some findings were made for Turkey with help of examining the current status of tax audits based on risk analysis. In the past, risk analysis was used for providing effectiveness of tax audit, but today the purpose has evolved to focus increasing tax compliance. For realization of this purpose in Turkey, disclosure of risk areas in general, informing taxpayers and establishment of cooperative compliance model with large business is needed.
\end{abstract}

\section{MAKALE Bígisi}

Alındı: 25.02.2016

Gözden geçirilmiş

alındı: 22.04.2016

Kabul: 28.04.2016

Yayın: 26.12.2016

\section{Ö ZE T}

Bilgi teknolojilerinin ve risk analizinin kullanımı, tüm alanlarda olduğu gibi, vergi denetiminde de önemli bir konuma gelmiştir. Kullanılan sistemler ise birçok yönden değişiklik göstermektedir ve bu sebeple karşılaştırmalı çalışmaların yapılması, en iyi uygulamaların değerlendirilerek, sonuçlara etkilerinin araştırılması gerekmektedir. Bu çalışmada Avusturalya, Birleşik

\footnotetext{
* 15-19 Mayıs 2016 tarihleri arasında düzenlenen 31. Türkiye Maliye Sempozyumu’nda sunulan metnin gözden geçirilmiş ve düzeltilmiş hâlidir.

Bu çalışma, doktora öğrencileri için TÜBiTAK 2214-A Yurt Dışı Araştırma Burs Programı kapsamında desteklenen, Avusturya'daki Vienna University of Economics and Business (Wirtschaftsuniversität Wien) Institute for Austrianand International Tax Law'da 2015 yılında tamamlanan araştırmanın sonuçlarından yola çıkılarak hazırlanmıştır. TÜBITAK'a desteğinden dolayı teşekkür ederiz.

1 Araş. Gör., Uludağ Üniversitesi iïBF Maliye Bölümü, feridebakar@uludag.edu.tr

2 Prof. Dr., Uludağ Üniversitesi iïBF Maliye Bölümü, agercek@uludag.edu.tr.
} 
JEL Kodu:

$\mathrm{K} 34, \mathrm{~K} 33, \mathrm{H} 26$

Anahtar Kelimeler:

Vergi Denetimi, Risk

Analizi, Vergi

Denetiminin Etkinliği
Krallık, Avusturya ve ABD'deki risk analizi sistemlerinin gelişimi araştırılmış ve bunun vergi denetiminde etkinliği sağlamadaki yeri ortaya konmaya çalışılmıştır. Böylece risk analizine dayalı vergi denetiminin son durumu incelenerek; ülkemiz için bazı tespitler yapılmıştır. Önceleri vergi denetiminde etkinliği sağlamak için kullanılmaya başlanan risk analizi, günümüzde bu amacını geliştirerek vergi uyumunu artırmaya yoğunlaşmıştır. Söz konusu amacın ülkemizde de ön planda olması için genel olarak risk alanlarının açıklanmasına, mükelleflerin bilgilendirilmesine ve büyük mükelleflerle işbirlikçi uyum modelinin kurulmasına ihtiyaç vardır.

\section{Giriş}

Bilgi teknolojilerine dayalı sistemler, maliyetleri azaltmak ve zaman tasarrufu yoluyla etkinliği sağlamak için tüm alanlarda kullanılmaktadır. Vergi denetimi de teknolojik gelişmelerden etkilenmiş; hem mükelleflerin gönüllü uyumunu hem de etkinliği artırmak için değişime uğramıştır. Vergi idarelerinde bu amaçla kullanılan risk analizi; riskli sektör, dönem ve mükellefleri tespit etme ve denetimleri bunlara yoğunlaştırma açısından önemlidir. Bu sebeple günümüzde vergi idareleri denetimde risk analizini, geliştirdikleri programlarla etkin bir şekilde kullanmaktadır.

Risk analizinde kullanılan sistemler; gelişimleri, kullanılacak veriler, programlar ve kapsamları yönünden ülkeden ülkeye değişiklik göstermektedir. Bu çalışmanın amacı; riske dayalı vergi denetimine geçiş sürecini ve çeşitli ülkelerde vergi idarelerinde kullanılan risk analizi sistemlerindeki farklı uygulamaları inceleyerek, ülkemizde vergi denetiminde uygulanan risk analizine dayalı sistemleri karşılaştırmak ve geliştirilmesine yönelik tespitler yapmaktır. Bu amaçla çalışmada öncelikle vergi denetiminde risk analizi uygulaması ve klasik denetimden risk analizine dayalı denetime geçiş süreci açıklanmıştır. Daha sonra Avusturalya, Birleşik Krallık, Avusturya ve ABD'deki örnek uygulamalardan yola çıkılarak, risk analizine dayalı vergi denetimine yönelik sistemlerde gelinen son durum ortaya konulmaya çalışımıştır. Son olarak Türkiye'deki uygulamalar incelenmiş, değerlendirme ve öneriler sunulmuştur.

\section{Vergi Denetiminde Risk Analizi Uygulaması}

Bir vergi sisteminin başarısı, verginin yasal altyapısının yanı sıra mevzuatın uygulanması ve uygulamanın denetlenmesiyle de ilgilidir (Schmölders, 1976: 97). Vergi denetimi mükelleflerin mevzuata uygun davranıp davranmadıklarını belirlemeye yönelik idare tarafından yapılan işlemler bütünüdür (Tekin, Çelikkaya, 2016: 51). Sistem içinde her mükellefin beyanının ayrı ayrı incelenmesinin ve bunların doğruluğunun araştırılmasının zaman ve idari maliyeti sebebiyle (Turhan, 1993: 82) günümüzde vergi idareleri, bilgisayar destekli sistemleri aktif olarak kullanmaktadır.

Vergi idarelerinin gerçekleştirdiği görevlerine ilişkin, ihtiyaç duydukları bilgilerin gerekli ölçüde ve nitelikte elde edilmesi ile bunların sağlıklı şekilde analiz edilebilmesi, vergi denetimi için önem taşımaktadır. Günümüzde vergi denetiminin etkinliğini belirleyen faktörler arasında bilgisayar destekli sistemlerin aktif olarak kullanılıp kullanılmadığı da bir kriter olarak kabul edilmektedir. Bilgisayar destekli sistemlerin 
doğru olarak kullanılması, saha denetimini daha etkin hale getirmektedir. Vergi denetiminde kullanılan risk analizi; riskli sektör, dönem ve mükellefleri tespit etme ve denetimleri bunlara yoğunlaştırma açısından belirleyici olmaktadır (Akbey, 2014: 70, 73).

Mükelleflerin ekonomik faaliyetleri ve vergi ile ilgili her türlü bilgisi, onların beyanları ve üçüncü kişiler tarafından sağlanan ya da idare tarafından ulaşılan bilgilerle birlikte risk analizi sistemleriyle incelenerek, önceden belirlenen kriterler çerçevesinde değerlendirilmekte ve riskli mükellefler sistematik bir şekilde gruplandırılmaktadır (European Commission - EC, 2006: 26-27). Denetimler riskli mükellefler üzerine yoğunlaştırılarak; sürecin idari maliyetlerinin azaltılması, sınırlı zaman ve kaynakların en etkin şekilde kullanılması ve denetim faaliyetlerinin verimliliğinin artırılması sağlanmaktadır. Riskli durumların bilgisayar sistemiyle tekrar incelenmesi sağlandığından, denetim elemanı ve mükellefler arasındaki etkileşim en aza indirilmekte ve bu yolla mükelleflerin uyum giderleri azaltılmaktadır (Gill, 2003: 16).

Risk analizine dayalı verimli bir denetim stratejisi, vergi uyumsuzluğu olasıllğı daha fazla olan mükellefleri tespit etmeye çalışırken, her mükellefe belirli davranışlarına ve önceki denetimlerden elde edilen bilgilerine yönelik bir puan verir. Hesaplamaların güvenilirliği için kullanılan bilgilerin niteliği kadar, analizde kullanılan yazılım da önemlidir (Vellutini, 2011a: 20). Bilgisayar sistemleri aracılığıyla; veri eşleştirme, istatistiksel metotlar, parametrik metot (doğrusal ya da lojistik regresyon analizi), parametrik olmayan yöntem olarak veri madenciliği (karar ağaçları, sinir ağları ve kümeleme analizi) yapılarak riskler hesaplanmaktadır (Vellutini, 2011b: 23-28).

Günümüzde risk analizinde kullanılan kaynakları şu maddelerde sınıflandırabiliriz: (Baurer, 2005: 38; EC, 2006: 27): ekonomik ve vergiye yönelik bilgiler (ekonomik büyüme oranları, ortalama ücret vb.), mükellefler tarafından verilen bilgiler (beyannameler, beyan edilen yüksek yönetim giderleri, düşük kar marjları, şüpheli faturalar ve olağan dışı bilançolar, bilgi verme kapsamında istenen veya düzenli verilen bilgiler vb.), idarede tutulan vergisel bilgiler (vergisel ödevleri veya beyanname verme tarihlerine uyum, mükelleflerin önceki denetim sonuçları vb.), diğer idarelerden alınan bilgiler (gümrük, SGK vb.), üçüncü kişiler tarafından sağlanan bilgiler (bankalar, borsa, tapu kayıtları vb.),seçilen bazı sektörler (alkol, tütün, akaryakıt, gaz vb.), internetten sağlanan bilgiler. Bu bilgilerin kullanımı; idarenin bilgiye erişim kapasitesi, mevzuattaki yasaların izin vermesi, fazla bilgilerin ayıklanma zorluğu, kullanılan bilgi teknolojilerinin kapasitesi ve yeni verilere ulaşma maliyetleri sebebiyle sınırlı olabilir (EC, 2006: 27).

\section{Klasik Vergi Denetiminden Risk Analizine Geçiş}

Vergi idarelerinin tıpkı şirketlerdeki kurumsal yönetim gibi bir modern sistem geliştirmeleri ve bu şekilde faaliyetlerinde etkinlik sağlamaları birçok faktörün yanında idarede risk yönetiminin oluşturulmasını gerekli kılmıştır. Risk yönetimi vergi uyumunun etkili ve verimli idaresi için önemlidir (Khwaja, 2011: 1).Bir denetimin başarısında; sadece sayısal olarak fazla denetim yapılması değil, aynı zamanda etkinliği de önemlidir. Vergi denetiminin etkinliği; mali yılda tamamlanan denetim sayısı, denetimler sonucunda tarh eden ek verginin tutarı, denetim sonucunda verilen cezaların toplam tutarı, ek vergi ve cezaların ortalama doğruluk oranı, denetlenen 
mükellef başına düşen ek vergi tarhiyatı ve cezalar, denetim sonucunda uygunsuzluk görülenlerin toplam denetim içindeki payı, denetimler sonucunda değişmeyen tarhiyat oranı ve denetime tahsil edilen toplam kaynak vb. sayısal verilerle ölçülmektedir (Crandal, 2010: 6; OECD, 2006: 29). Denetimin etkinliğini belirleyen göstergelerden biri de mükellef seçimidir. Hangi mükelleflerin denetlenmesi gerektiğini etkinlikle belirlemek için, vergi denetiminde risk yönetimi uygulanmaya başlanmışlardır (Russo, 2010: 180). Mükellef seçimi aracılı̆̆ıyla denetimde etkinliği artırmak, denetim stratejilerinin risk analizine dayanması ve yüksek riskli mükelleflerin denetlenmesiyle mümkündür (Arslan, Biniş, 2016: 443-444). Denetimde risk analizinin önemi aşağıdaki gibi belirtilebilir(GiB, 2009: 103):

- Denetim politikalarının oluşturulmasında destek sağlamak ve denetimin planlamasında hedeflere ulaşmayı kolaylaştırmak,

- Mükelleflerin sektörler itibariyle ayrıştırılmasıyla, sektörel analiz imkanı sağlamak,

- Yeni mükellefiyetlerin tespit edilmesine yol göstermek,

- Tahakkuk ve tahsilat analizleri ile ödemelerde uyum göstermeyen mükellefleri daha hızlı tespit etmek,

- Mükelleflerin vergiye olan dirençlerini belirleyebilmek,

- Denetimlerin daha hızlı tamamlanması ve yıl içindeki işlemlerin kolaylıkla izlenmesini sağlamak.

Vergi idareleri her zamankinden daha önemli hale gelen bir risk yönetim süreci içinde değerlendirmeler yapmaktadırlar. Bunun nedeni; iş yaşamındaki karmaşıklık ve yenilikler sebebiyle idarenin karşı karşıya kaldığı risklerin çoğalması, yeni finansal ürünlerin ortaya çıkması, vergiye tabi kişilerin ve hizmetlerin sayısının artması, eticaretteki gelişmeler vb. durumlardır. Ayrıca günümüzde kamu kesiminin daha verimli çalışma gereksinimi ön plandadır. Vergi idareleri de sadece kamusal hizmetlerde değil, bütçe ve personel kullanımı açısından da etkinliği artırmaya çalışmaktadırlar (EC, 2006: 7). Aşağıdaki şekil yardımıyla risk analizine dayalı ve klasik vergi denetimi arasındaki farkı ortaya koyabiliriz. Risk analizinde denetim planları, merkezi sistem içinde denetim seçimi ile yapıldığından kaynakların verimli bir şekilde kullanılması sağlanacaktır.

Şekil 1. Klasik Vergi Denetimi ve Riske Dayalı Vergi Denetimi Süreci

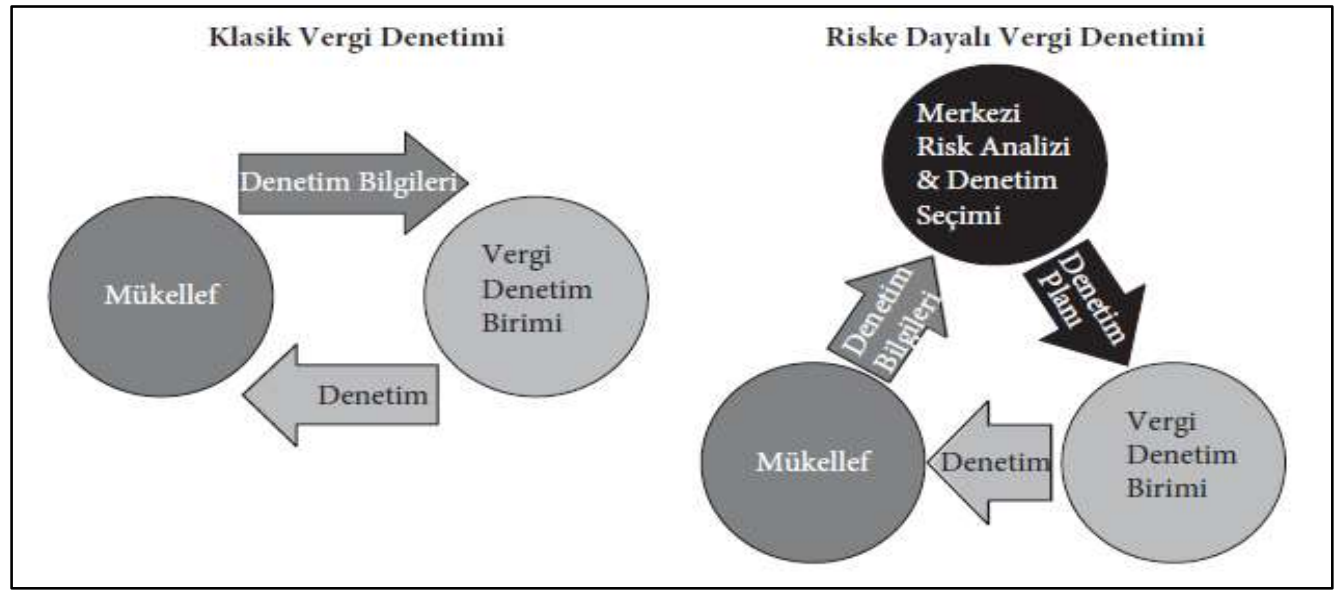

Kaynak: Vellutini, 2011a: 16. 
Vergi idaresindeki risk analiz teknikleri sadece denetlenecek mükellefleri seçmek için değil, aksine vergi uyumunu artırmak için bütünsel ve işbirlikçi bir yaklaşım içinde kullanılmalıdır (Khwaja, 2011: 4).Denetimde risk analizinin uygulanması gönüllü uyumu teşvik etmek için şu şekilde kullanılır (Vellutini, 2011a: 15):Denetimler uyumsuz mükellefleri tespit etmek ve uyumsuzluk gösterdikleri alanları düzeltmek için uygulanır; uyumsuz olan mükelleflerin tespit edilmesi ve cezalandırılma olasılıklarının artmasıyla denetimler gönüllü uyumu teşvik eder; denetimler, hem vergi sisteminin düzgün işleyişini hem de mükellefler tarafından kullanılan vergi kaçırma tekniklerinin anlaşılması için önemlidir.

Bu sebeple $O E C D$, ülkelerde vergi gelirlerinin yükselmesi amacıyla gönüllü uyumu artırmayı teşvik etmekte ve vergi idarelerinde risk analizinin kullanımını uzun yıllardır tavsiye etmektedir. İlk çalışması 1997 'de “Risk Yönetimi" uygulama notunun yayınlanmasıyla başlamıştır. Bu çalışma genel risk yönetimi kavramı ve onun vergi idaresiyle bağlantısını açıklamaya yöneliktir (Bkz. OECD, 1997). 2001 yılında yayınlanan "Uyum Ölçümü" ise; uyumu belirleyici bir dizi konuyu açıklayan ve mükelleflerin uyumunu ölçmeye yönelik çalışmaların kısa özetlerini sağlayan bir rapordur. Söz konusu rapor özellikle büyük kurumsal mükelleflerin uyum ya da uyumsuzluk davranışını ölçmeye yönelik çalışmaları artırmayı amaçlamaktadır (OECD, 2008: 6).

2002'de bir dizi OECD ülkesinin vergi yetkilileri, uyum riski yönetimi stratejilerini paylaşmak ve bu konuya rehberlik edecek belgeler konusunda anlaşmak için Vergi İdareleri Uyum Alt Grubu Forumu'nda toplanmıştır. Uyum Alt Grubu tarafından yapılan çalışmalar ve raporlar şu noktalar üzerinde durmaktadır (OECD, 2004a: 5): vergi uyumunu yönetmek ve artırmak, uyum araştırma projeleri kataloğu, uyum stratejileri kataloğu, denetim vaka seçim sistemi, rasgele seçim programlarının kullanımı. 2004'te yayınlanan "Uyum Riski Yönetimi: Vergi Uyumunu Yönetmek ve Artırmak" raporu, uyum riski yönetimi ile ilgili bir model içermektedir. Bu model; risklerin tespit edilmesi, belirlenmesi ve önceliklendirilmesi, vergi uyum davranışının analizi, önleme stratejilerinin belirlenmesi, plan ve uygulama stratejilerinin geliştirilmesi, uyum çıktılarının değerlendirilmesi ve modelin genel performansının planlara uygunluğunun izlenmesi aşamalarından oluşmaktadır (OECD, 2004a: 9). Aynı dönemde yayınlanan "Uyum Riski Yönetimi: Denetim Vaka Seçim Sistemi" raporu bazı ülkelerin örnek risk analizi uygulamalarına yoğunlaşmaktadır (Bkz. OECD, 2004b).2008'de Uyum Alt Grubu "Mükellef Uyumunun İzlenmesi: Gelir İdaresi Deneyimlerine Dayanan Bir Uygulama Rehberi”ni yayınlamıştır (OECD, 2008). OECD’nin uyum çalışmaları daha sonraki dönemde küçük ve orta ölçekli işletmelere yoğunlaşmıştır. Bunun temel nedenlerinden biri büyük mükellefler için ayrı uyum modellerinin ortaya çıkmaya başlamasıdır (OECD, 2009).

OECD'nin iki yılda bir yayınladığı vergi idareleri karşılaştırma raporunun 2015 versiyonu, bu konudaki son gelişmeleri içermektedir. Rapora göre ülkelerde vergi konusunda en riskli beş alan tespit edilmiştir. Buna göre 34 OECD ülkesinden 27'sinde KDV hileleri, 22'sinde kayıt dışı ekonomideki aktiviteler, 21 ülkede transfer fiyatlandırması, 19 ülkede transfer fiyatlandırması dışındaki diğer vergiden kaçınma planlamaları ve 18 ülkede ise ödenmemiş vergi borçları vergi riski en fazla olan alanlar olarak açıklanmıştır (OECD, 2015: 130). Aşağıdaki Tablo 1'de OECD ülkelerinde 
uygulanan denetimde risk analizinin genel görünümü incelendiğinde, 34 OECD ülkesinin hepsinde denetimde risk analizinin kullanıldığı görülmektedir. Bunlardan 19 ülkede rasgele seçim yöntemi, risk analizi sistemini kontrol mekanizması olarak işletilmektedir. Ayrıca 23 ülkede büyük mükelleflerle işbirlikçi uyum modeli uygulanmaktadır. Buna ilave olarak, 20 ülkede önemli riskler ve bunlara yönelik stratejiler, 27 ülkede ise sonuç raporları kamuoyuna açıklanmaktadır.

Tablo 1. OECD Ülkelerinde Denetimde Risk Analizinin Genel Görünümü

\begin{tabular}{|c|c|c|c|c|c|}
\hline Ülkeler & $\begin{array}{l}\text { Risk Analizi } \\
\text { Sisteminin } \\
\text { Resmi } \\
\text { Olarak } \\
\text { Kullanımı } \\
\end{array}$ & $\begin{array}{l}\text { Rasgele } \\
\text { Seçimle } \\
\text { Denetim }\end{array}$ & $\begin{array}{c}\text { Büyük } \\
\text { Mükelleflerle } \\
\text { İşbirlikçi Uyum } \\
\text { Modeli } \\
\text { Kullanımı } \\
\end{array}$ & $\begin{array}{c}\text { Önemli Risk } \\
\text { ve } \\
\text { Stratejilerin } \\
\text { Açıklanması }\end{array}$ & $\begin{array}{l}\text { Sonuç } \\
\text { Raporlarının } \\
\text { Kamuoyuyla } \\
\text { Paylaşılması }\end{array}$ \\
\hline ABD & Var & Var & Var & Var & Var \\
\hline Almanya & Var & Var & Yok & Yok & Yok \\
\hline Avustralya & Var & Yok & Var & Var & Var \\
\hline Avusturya & Var & Var & Var & Yok & Var \\
\hline Belçika & Var & - & - & Yok & Var \\
\hline Birleşik Krallık & Var & Var & Var & Var & Var \\
\hline Çek Cumh. & Var & Yok & Yok & Yok & Var \\
\hline Danimarka & Var & Var & Var & Var & Var \\
\hline Estonya & Var & Var & Yok & Var & Var \\
\hline Finlandiya & Var & Var & Pilot Proje & Yok & Yok \\
\hline Fransa & Var & Var & Var & Yok & Yok \\
\hline Hollanda & Var & Var & Var & Var & Var \\
\hline İrlanda & Var & Var & Var & Yok & Var \\
\hline İspanya & Var & Yok & Var & Var & Var \\
\hline İsrail & Var & Var & Var & Var & Yok \\
\hline İsveç & Var & Yok & Var & Var & Var \\
\hline İsviçre & $\operatorname{Var}(\mathrm{KDV})$ & Var & Var & Yok & Var \\
\hline İtalya & Var & Yok & Var & Yok & Var \\
\hline İzlanda & Var & Var & Yok & Yok & Var \\
\hline Japonya & Var & Var & Yok & Var & Var \\
\hline Kanada & Var & Var & Var & Var & Var \\
\hline Kore & Var & Yok & Var & Yok & Yok \\
\hline Lüksemburg & Var & Var & Yok & Var & Yok \\
\hline Macaristan & Var & Var & Yok & Var & Var \\
\hline Meksika & Var & Yok & Var & Var & Var \\
\hline Norveç & Var & Var & Var & Yok & Var \\
\hline Polonya & Var & Yok & Var & Var & Var \\
\hline Portekiz & Var & Yok & Var & Yok & Var \\
\hline Slovakya & Var & Yok & Var & Var & Var \\
\hline Slovenya & Var & Yok & Var & Var & Var \\
\hline Şili & Var & Yok & Yok & Var & Var \\
\hline Türkiye & Var & Var & Yok & Yok & Var \\
\hline Yeni Zelanda & Var & Yok & Var & Var & Var \\
\hline Yunanistan & Var & - & - & Var & Var \\
\hline
\end{tabular}

Kaynak: OECD (2013b) ve OECD(2015) raporlarından derlenerek oluşturulmuştur. 


\section{4. Çeşitli Ülkelerde Vergi Denetiminde Risk Analizi Uygulamaları}

Ülkelerde vergi idareleri kamu gelirlerinin tahsilatına yetkiliyken, aynı zamanda bu gelirlerin sürekliliği için önemli olan vergi uyumunu artırıcı ve koruyucu politikaları da sürdürmektedir (Benk, Kartalcı, 2015: 44). Bilişim teknolojilerinin ortaya çıkması ve hızı bir gelişim göstermesi, devletin birçok mekanizmasının elektronik ortama geçmesini birlikte getirmiştir. Bu süreç devlet kurumlarının, bilgi ve iletişim teknolojilerinden en üst seviyede yararlanmasını zorunlu kılmıştır (Gerçek vd., 2013: 17). Günümüzde vergi idareleri temel gereksinim haline gelen teknolojik altyapıyı özellikle vergi uyumunu artırıcı ve koruyucu politikaları oluşturmak için kullanmaktadır. Vergi denetiminde risk analizi de bu sebeple kullanılan bir yöntemdir. Bu yöntemin kullanımında ise çeşitli uygulamalar söz konusudur. Bu başlık altında Avusturalya, Birleşik Krallık, Avusturya ve ABD seçilen ülke örnekleri olarak incelenmiştir.

\subsection{Avusturalya Vergi İdaresi'nin (ATO) Denetimde Risk Analizi Uygulaması}

Avusturalya'da 1986 yılında beyana dayalı sisteme geçişle birlikte, beyanlar sonrası uyum gösteren ve göstermeyen mükelleflerin belirlenmesi açısından denetim önem kazanmıştır. Bu sebeple, denetim yapılacak mükellefleri seçme açısından teknikler geliştirilmeye başlanmıştır. 1988 yılında ise denetimler; karmaşık denetim, işletme denetimi ve öncelikli denetim olarak sınıflandırılarak, denetim aktiviteleri ilk defa sistematize edilmiştir. Aynı yıl bazı sektörlerde bilgi toplamak ve vergiye uyum davranışlarını öğrenmek için denetime dayalı projeler geliştirilmiştir. 1990'lardan itibaren idare, mükellefleri tür ve boyutlarına göre segmentlere ayırmış ve her segmente göre; hizmet sunumu, denetim, sistem ve tahsilata yönelik uygun yaklaşımı tespit etmeye çalışmıştır(Whait, 2012: 448).ATO (Australian Tax Office)benimsediği idarenin elindeki kaynakları heba etmemeyi sağlayan "idari etkinlik" anlayışını her alanda uygulamaya çalıştığı için, denetim seçimi ve tamamlanma sürecini de bu hedef doğrultusunda şekillendirilmiştir (Whait, 2012: 447). Denetimde risk analizleri, genelde sadece idarede tespit kapasitesini geliştirerek daha iyi vergi denetim seçimine odaklanan bir süreçtir. Fakat denetim hem mükellefler hem de ATO için çok maliyetlidir. ATO'nun 2001 yılından itibaren resmi olarak uygulamaya başladığı vergi uyum modeli ise, en iyi denetim seçiminin ötesine geçmeyi amaçlayan bir yapıda olup, mükellefi anlayan ve uyuma doğru yönlendiren bir sistemdir (Inspector-General of Taxation - IGT, 2013: 15).

ATO'nun uyguladığı vergi riski analizi en eski uygulamalardan birisi olup, bir uyum modeli kullanarak çalışmaktadır (Freedman, 2010: 116). ATO'nun kabul ettiği vergi uyumu modeli Australian National University ile birlikte geliştirilmiştir. OECD de yayınladığı raporlarda bu modelin kullanılmasını önermiştir. Model, mükellefleri vergi uyumu ve/veya uyumsuzluğu konusunda etkileyen ya da motive eden faktörleri belirlemeye odaklanmıştır (Benk, Kartalcı, 2015: 52). Bu sistemde amaç; mükellefleri doğru olanı yapmaya yönlendirmek ve yaptıkları şeyleri mümkün olduğunca kolay yapmalarını sağlamaktır (ATO, 2013: 2).

ATO'nun kabul ettiği uyum modeli Şekil 2'de görülmektedir. Bu modelde mükellefleri davranışlarını etkileyen beş faktör belirlenmiştir. Ayrıca bu faktörlerin 
etkileri sonucunda mükelleflerin dört basamaklı bir strateji içinde, hangi noktada oldukları belirlenerek, bu doğrultuda onlara hizmet sunulmakta ve/veya zorlama yapılmaktadır. Örneğin uyum konusunda isteksiz fakat dikkat edilirse uyum sağlayabilecek mükelleflere, kısmen caydırıcı güç kullanılırken; vergiye gönüllü uyum sağlayan mükelleflerin ise vergi ödemeleri ve bunlara yönelik ödevleri kolaylaştırılmaya çalışılmaktadır.

Şekil 2. ATO Vergi Uyum Modeli

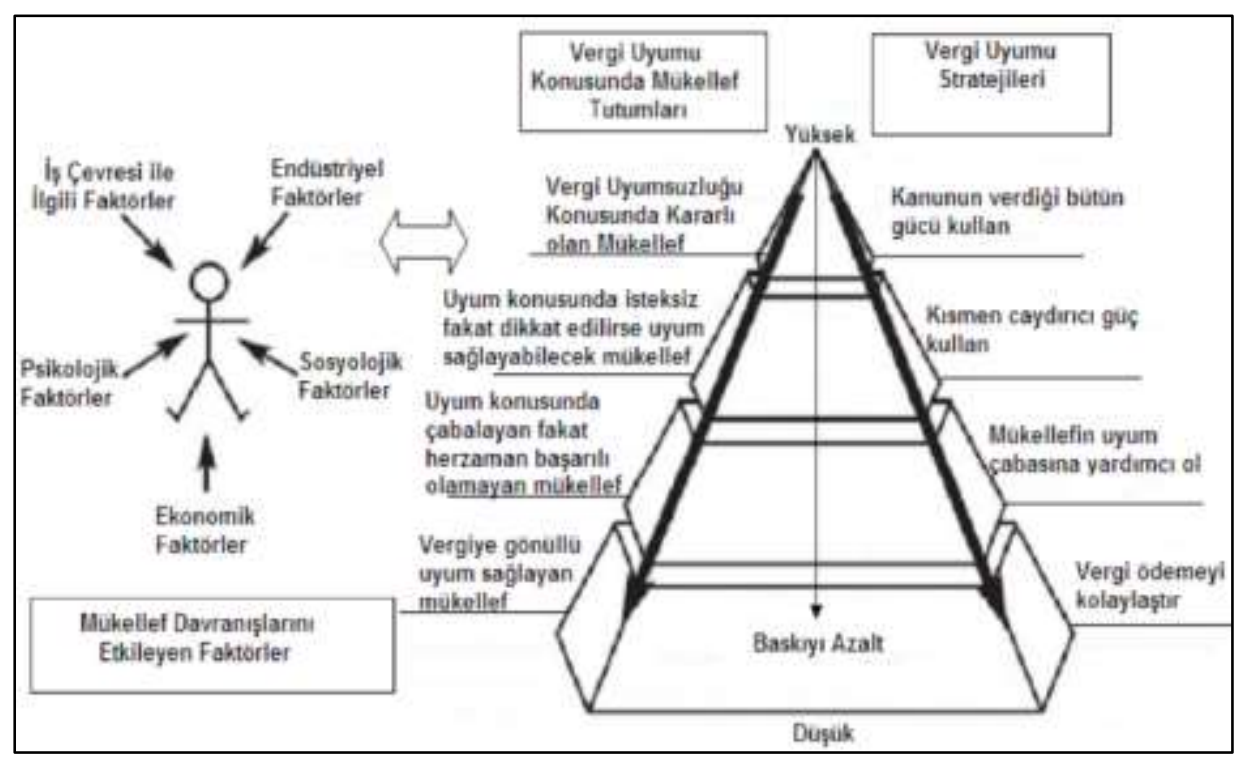

Kaynak: Benk, Kartalcı, 2015: 52.

Uyum Modeli; vergi uyumu göstererek, vergisel ödevlerini zamanında yerine getiren mükelleflere karşı mümkün olduğunca esnek, bunun tersi olarak uyumsuz mükelleflere ise oldukça sert yaptırımlar uygulama sürecini oluşturur (Dökmen, Günel, 2012: 51). Uyum davranışını etkileyen faktörleri tespit etmeyi amaçlayan model, farklı uyum gösteren mükelleflere, gösterdikleri bu davranışlara göre davranma üzerine kuruludur. Bu sebeple risklerin giderilmesi için her gruba farklı stratejiler uygulanır. Stratejiler, mükellefleri doğru olanı yapmaya yönlendirerek, daha fazla kişinin gönüllü uyum göstermesine yardımcı olmayı amaçlar (ATO, 2013: 3).idare, uyum stratejisini uyguladığından beri; vergi gelirlerinde yükselme, beyannamelerin zamanında verilmesinde ve beyanname sayısında artış gözlenmiştir. Bu durum modelin başarısını göstermektedir (Dökmen, Günel, 2012: 55-60).

ATO, tespit ettiği farklı aşamalardaki mükelleflere en uygun yaklaşımı belirlemek için farklı araçlar kullanmaktadır (IGT, 2013: 25). Uyum analizinde kullanılan bilgi ve eşleştirme kapasiteleri her yıl genişletilmekte ve geliştirilmektedir. Her yıl ATO, 640 milyonun üzerinde işlemin düzgün olarak bildirildiğini ve iddiaların doğruluğunu kontrol etmektedir (ATO, 2013: 2). Yaptığı protokoller yardımıyla ATO; bankalardan, finansal ve yatırım kuruluşlarından, işverenlerden, motorlu araç tescil organlarından, tapu dairelerinden, diğer devlet organlarından, Avusturalya İşlem Raporlama ve Analiz Birimi'nden, uluslararası anlaşmalı birimlerden, ticari kredi ve banka kartı 
kullanımlarından, borsalar ve hisse senedi kayıtlarından, inşaat ve yapı sektöründeki işletmelerden, sağlık sigortalarından (Bkz. ATO, https://www.ato.gov.au/General/ Building-confidence/In-detail/Data-matching/Sources-of-information/) elde edilen bilgilerle veri eşleştirmesi yapılmaktadır. Avustralya'da uygulanan sektörel analizlere paralel olarak, 58 kriter geliştirilmiştir. Bu kriterler malın maliyeti, işgücü maliyeti ve kira maliyetleri gibi işlemleri belirleyerek, sektörel normlara aykırılıkları izler. En riskli sektörler; inşaat, taşımacılık, restoran, kuaför ve güzellik salonları, temizlik servisi, tekstil, motorlu araç bayileri, sanat eşyası ve antika satıcıları olarak belirlenmiştir (Loeprick, Engelschalk, 2011: 50). Avustralya'da 2014 yılı için en riskli 5 vergi alanı; transfer fiyatlandırması ile bunun dışındaki diğer vergiden kaçınma yolları, KDV hileleri ile bunun dışındaki diğer vergi hileleri ve kayıtdışı ekonomideki faaliyetler olarak açıklanmıştır (OECD, 2015: 19).ATO ulaştığı bilgileri gizlilik hakkı çerçevesinde; 1936 tarihli Gelir Vergisi Kanunu'nun ve 1953 tarihli Vergilendirme İdaresi Kanunu'nun gizlilik hükümlerine ve 1988 tarihli Bilgileri Koruma Kanunu'na uygun bir şekilde saklamaktadır.

Uygulanan vergi uyum modeli, Haziran 2003'te şirketlerde vergi yönetimini teşvik etmek için Büyük Mükellefler ve Vergi Uyumu (Large Business and Tax Compliance) programıyla devam etmiştir (Wunder, 2009: 15). Bu programda ATO, şirketleri vergi riski yönetiminin önemini anlamak ve kendi risk yönetim politikalarını oluşturmak için teşvik etmektedir (Henehan, Walsh, 2008: 19).Modelin özü denetime odaklı bir temelden çok, özellikle ilk 100 büyük mükellef için, zamanında vergi risklerini yöneterek, kullanılabilir bir belirlilik ve kaynak yönetimine elverişli bir uyum stratejisi oluşturulmasına dayanır. ATO ve düzenlemeye katılmak isteyen gönüllü mükellefler arasında uygulanan Yıllık Uyum Anlaşması; iyi bir vergi yönetişim süreci ve önemli vergi risklerinin zamanında, tam ve doğru şekilde açıklanması için şeffaf ve açık bir ortam sağlar (OECD, 2013a: 26).

\subsection{Birleşik Krallık Gelir İdaresi'nin (HMRC) Denetimde Risk Analizi Uygulaması}

Birleşik Krallık'ta gelir idaresi (Her Majesty's Revenueand Customs - HMRC) riske dayalı denetimlere 1980'li yıllardan itibaren dolaysız vergilerde yerel düzeyde başlamıştır.1983 yılından itibaren ise "KDV Merkezi Risk Analizi” adı altında gümrük ve tüketim vergileri için yıllık olarak üretilen risk değerlendirmesi, hem politikaları oluşturan hem de işlemleri uygulayan personel tarafından kullanmaktadır (EC, 2006: 89). Beyana dayalı sistemin başlamasıyla birlikte ihtiyaç duyulan risk değerlendirmesi sistemi, 2000 yılında genel araştırma biriminden ayrılarak uzmanlaşmış, 2005 yılında ise ulusal düzeyde kurumsallaşmıştır. Bu sistemde risk kuralları ve risk segmentleri belirlenmiştir. Beyannameleri gruplandırma ve tahminleme yoluyla yapılan analize, veri eşleştirme ve toplanan istihbarat yardımcı olmaktadır. Riske stratejik bir şekilde yaklaşım için mükelleflerin ulusal düzeyde derecelendirilmesi yapılmaktadır. Ticari aktivitelerin sektörel standartlarla karşılaştırılmasında oluşan anormallikleri tespit etmek için ticari sektör danışmanlarıyla görüşmeler yapılmaktadır. Risk istihbarat Servisi; üçüncü kişilerden, uluslararası kaynaklardan, gizli, açık ve ticari bilgilerden, gönüllü verilen ya da yönetim bilgilerinden yola çıkarak; sektör özelliklerine göre eğilimleri izlemekte ve davranışları tahmin etmektedir. Entegre Uyum Ortamı'nda 
toplanan verilerin kullanılmasıyla; çalışmalarda verim artışı, personel verimliliği ve çeşitli stratejik faydalar sağlanmaktadır (Hainey, 2011: 65-70).

HMRC mükelleflerin uyum davranışını 54 temel risk alanında ve 2 önemli risk alanında tespit etmeye çalışmaktadır. Öncelikle mikro, küçük, orta büyüklükte ve büyük işletmeler, örgütlü suçlar, belirli bir tutarın üzerindeki bireysel zenginlik ve kitlesel pazar ölçütlerine göre ayrıştırılan mükellefler, daha sonra bunların her birinin alt grubunda sınıflandırılmaktadır. Örneğin mikro işletmeler 8 alt risk grubuna, büyük işletmeler ise 15 alt risk grubuna göre tekrar değerlendirilmektedir. Alt gruplarda; ödenmeyen vergiler, hatalar, hukuki yorum ve vergiden kaçınma, kayıtdışı ekonomi ve vergi kaçırma ile kriminal davranışlara göre farklı kriterler yer almaktadır (HMRC, 2015: 214-215). Şekil 3, risk alanlarının genel görünümünü göstermektedir.

Şekil 3. HMRC Temel Vergi Riski Alanları

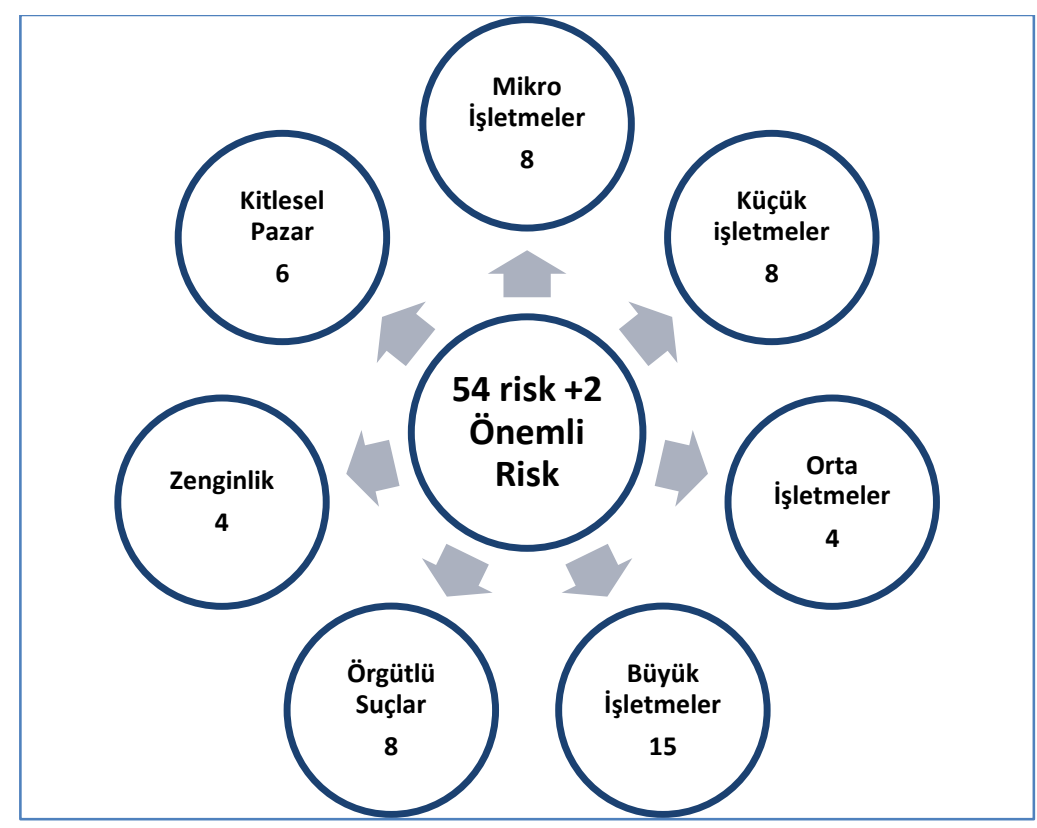

Kaynak: HMRC, 2015: 215.

HMRC uyum ölçüm işlemleri, vergi açığının (boşluğu) boyutunu bulmak ve bunu azaltmak üzerine yoğunlaşır. Bu açığın ölçülmesi gönüllü uyumsuzluğun boyutunu ortaya çıkarmakta ve hedefler bu uyumsuzluğun azaltılmasına yönelik belirlenmektedir (OECD, 2008: 25). Birleşik Kralık'ta2014 yılı için en riskli 5 vergi alanı; transfer fiyatlandırması ile diğer vergiden kaçınma yolları, KDV dışındaki diğer vergi hileleri, kayıtdışı ekonomideki faaliyetler ve ödenmeyen vergi borçları olarak belirlenmiştir (OECD, 2015: 130).HMRC belirlediği politikaları gereği denetim sayılarını paylaşmamaktadır, fakat tahminler denetimlerin beyanname veren mükelleflerin yaklaşık \% 1'i olduğu yönündedir. HMRC sunduğu mükellef odaklı hizmet anlayışı gereği denetimlere değil, özellikle gönüllü uyumu artırmaya odaklanmaktadır. Örneğin 20142015 periyodunda idare tarafından 26,6 milyar fvergi uyumunu sağlamadan kaynaklı bir gelir elde edilmiştir. Bu gelir, mükelleflerin beyannamelerinde çeşitli hileli vergi 
kaçırma ve vergiden kaçınma davranışlarının idare tarafından tespit edilmesi sonucunda oluşmuştur. Tespitler; araştırma ve doğrulama faaliyeti sonucunda olabileceği gibi, aynı zamanda vergi boşluklarının yeni hukuki düzenlemelerle doldurulmasından sonraki önleyici işlemin sonucuna yönelik de olabilir. Her türlü tespit, temelde uyum davranışının korunmasını amaçlamaktadır ve bunlar sonucunda mükelleflerin adli ve idari olarak cezalandırılması söz konusu olabilir(HMRC, 2015: 1314, 221). Tablo 2 'de Birleşik Krallık ile ilgili bazı vergisel bilgiler yer almaktadır. Buna göre HMRC'nin hedeflediği vergi gelirlerini artırma stratejilerinin başarı ile devam ettiği söylenebilir. Ayrıca risk analizlerinin vergi açığını azaltmayı amaçladığı düşünüldüğünde, vergi açığı oranının düşmesi, etkin bir strateji izlendiğini göstermektedir.

Tablo 2. Birleşik Krallık'ta Vergiyle ilgili Bazı Bilgiler

\begin{tabular}{|l|r|r|r|r|r|}
\hline Değer & \multicolumn{1}{|c|}{$\mathbf{1 9 9 5}$} & \multicolumn{1}{c|}{$\mathbf{2 0 0 0}$} & \multicolumn{1}{c|}{$\mathbf{2 0 0 5}$} & \multicolumn{1}{c|}{$\mathbf{2 0 1 0}$} & \multicolumn{1}{c|}{$\mathbf{2 0 1 5}$} \\
\hline $\begin{array}{l}\text { Mükellef } \\
\text { Sayısı }\end{array}$ & 25.725 .000 & 27.920 .000 & 31.326 .000 & 31.643 .000 & 31.883 .000 \\
\hline $\begin{array}{l}\text { Vergi } \\
\text { Gelirleri }\end{array}$ & 235.2 Milyar $£$ & 336.6 Milyar $£$ & 426.5 Milyar $£$ & 485.7 Milyar $£$ & 533.4 Milyar $£$ \\
\hline Vergi Açı̆̆ı & - & $\% 14^{* *}$ & $\% 8.4$ & $\% 7.0$ & $\% 6.4^{*}$ \\
\hline $\begin{array}{l}\text { Vergi Açığı } \\
\text { Tutarı }\end{array}$ & - & - & 37 Milyar $£$ & 34 Milyar $£$ & 34 Milyar $£^{*}$ \\
\hline
\end{tabular}

*2014 hesaplamasını içermektedir.

** ilk kez 2001'de dolaysız vergiler için hesaplanmıştır.

Kaynak: HMRC istatistiklerinden yararlanılarak tarafımızca oluşturulmuştur.

HMRC benimsediği ilkelerin uygulanmasında, mükelleflere danışma sürecinden destek alarak, sistemin ve prosedürlerin geliştirilmesinde ticari bakış açısını dikkate almaya çalışmaktadır (OECD, 2013a: 19). Uyguladığı Büyük İşletmelerle iliş̧kileri Gözden Geçirme'nin (Review of Links with Large Business - RLLB) bir parçası olarak risk değerlendirmesini geliştirmektedir. HMRC, 2007 yılında büyük şirketler için işbirlikçi uyum yaklaşımını resmi olarak ilan etmiştir. Bu yaklaşım vergi uyum riski yönetimi kullanarak, mükelleflerle karşılıklı ilişkilerin yönetilmesine dayanmaktadır (OECD, 2013a: 24). Böylece HMRC ve mükellefler arasındaki güven ve şeffaflığa dayanan ilişkileri artırmayı desteklemektedir. Yaklaşımın amacı, kaynak tahsisini geliştirmek ve şirketlerin vergi planlaması stratejilerini değiştirerek düşük risk içeren davranışlara yönelmelerini sağlamaktır (Freedman, Loomer, Vella, 2009: 74). HMRC, özellikle vergi riski yönetimine dayalı etkin yönetişim ve kontrolü artırmayı amaçlayan; şirketlerle, işbirlikçi çalışmaları içeren bir doküman hazırlamıştır (Henehan, Walsh, 2008: 20).Sürecin temel özellikleri tüm büyük mükelleflerin risk açısından gözden geçirilmesi, mükelleflerle karşılıklı görüşme, risk statülerine göre program belirlenmesi ve görüşülmesi, son olarak da düşük riskli mükellefler için daha fazla destek ve daha az müdahaleyi içermektedir. Bu uygulama yüksek riskli mükellefler için kaynakların etkin kullanımına, sorunların hızlı çözümüne ve yeni işlemlerde danışma yardımıyla belirlilik sağlanmasına olanak tanımaktadır (Enden vd., 2010: 349). 


\subsection{Avusturya Federal Maliye Bakanlığı'nın Denetimde Risk Analizi Uygulaması}

Avusturya'da birçok alandan toplanan ulaşılabilir verilere dayalı risk analizi, etkinliği artırmak için kullanılmaktadır (Fritz, 2010: 152). Riske dayalı denetim, eşit vergilendirmeyi ve dürüst mükelleflerin korunmasını sağlamaktadır (BMF, 2013). Dahası, risk analizi dolandırıcılığa karşı mücadelede önemli bir rol oynamaktadır. 2004 yılında Maliye Bakanlığı'na ve onun Dolandırıcılıkla Mücadele Birimi'ne karşı sorumlu olarak kurulan; Risk, Bilgi ve Analiz Merkezi'nde (RIA) sistem, merkezi bir şekilde yürütülmekte ve stratejiler ile çalışma prosedürleri geliştirilmektedir. RIA, vergi ve gümrük işlemlerindeki risk yönetiminde yetkilidir ve sorumlu olduğu temel alanlar şöyledir(EC, 2006: 94-95): risk yönetim süreci, bilgilerin toplanması, değişimi ve analizi, denetim ve kontrol tekniklerinin geliştirilmesi, vaka seçimi ve denetim planlaması ve bu alanlarda uluslararası işbirliği faaliyetlerinin yürütülmesi.

Avusturya'da risk analizi öncelikle KDV, kâr üzerinden alınan vergiler ve denetim planları ile başlamıştır. Daha sonra gelir, kurumlar vergisi ve ücret maliyetleri kapsama alınmıştır. Günümüzde ise internet üzerinden sağlanan bilgiler, gümrük bilgileri ile kapsam genişlemektedir. Yapılan risk ölçeklendirme; mükelleflerin ticari faaliyetleri, girişimleri ve ödeme geçmişlerine dayalı olarak oluşturulan endekslerin; matematiksel, davranışsal ve diğer faktörlerle işlenmesiyle oluşur. Süreçte, matematiksel hesaplanamayan ama önemli durumları içeren ve "kırmızı bayrak" olarak adlandırılan bilgiler, daha sonra sistemde analiz edilmektedir (Fritz, 2010: 153).Ayrıca risk analizinde, olası ciroyu belirleme yöntemi olarak, sektördeki tahmini giderler kullanılmaktadır, bu şekilde 54 farklı iş aktivitesi için tahmini gider belirlenmiştir. Örneğin; tahmini gider oranları satış acentelerinde \% 12, demir işinde \% 16'dır(Loeprick, Engelschalk, 2011: 51). Avusturya'da 2014 yılı için en riskli 5 vergi alanı; transfer fiyatlandırması ile diğer vergiden kaçınma yolları, KDV hileleri, kaçakçılık gibi yasal olmayan aktiviteler ve ödenmeyen vergi borçları olarak belirlenmiştir (OECD, 2015: 130). Uyum riski yönetimi, risk indeksleme, veri madenciliği, sektör denetimleri, bölgesel risk yönetimi ve gümrük kontrol sistemi risk analizini geliştirmek için kullanılmaktadır (BMF, 2013: 18).Tablo 3'te Avusturya'da vergi ile ilgili bazı bilgilere yer verilmiştir. Buna göre, denetimler yoluyla en fazla ek vergi tarhiyatının büyük mükellefler üzerinde yoğunlaştığı görülmektedir. Bu mükelleflerin denetimleri toplam denetim içinde sayısal olarak fazla yer almamasına rağmen, özellikle KDV açısından uyumsuzluklarının fazla olduğu tespit edilmiştir. Risk analiziyle, mükellefleri gönüllü uyuma sevk etmek amaçlandığından, vergi gelirlerinde bir önceki yıla göre artış sağlanması, vergi denetimlerindeki azalmaya rağmen, bunlar sonucundaki ek vergi tarhiyatının artması, denetimde etkinlik açısından olumlu göstergelerdir.

Büyük mükelleflerin uyumsuzluklarını denetim içindeki ek vergi tarhiyatının payıyla ortaya koyan Tablo 3'teki bu durum, Avusturya'da idareyi, büyük mükellefler için özel bir stratejiye yönlendirmiştir.2011 yılında 10 büyük mükellefle pilot uygulamaya başlayan "Yatay İzleme (Horizontal Monitoring - HM)" projesi; vergi danışmanlarını içeren odalar gibi dış paydaşlar ile ticaret ve sanayi odasının katılımıyla gelişmeye devam etmektedir (OECD, 2015: 22). HM projesi, büyük şirketlerin idareyle ilişkilerini geliştirmeye dayanmaktadır ve karşılıklı danışmayı içermektedir. Büyük mükelleflere bir gözetim talebi sunulur, bunun sonucunda hem risk analizine dayalı 
vergi kontrol sistemi, hem de işbirliğine dayalı ilişkiler kullanılmaktadır. Bu karşılıklı ilişkide, sistemin gelişimi için düzenli toplantılar yapılmaktadır. 2013 yılında Yatay İzleme projesine katılan şirket sayısı $15^{\prime}$ e yükselmiştir. Şirketlerin bu projeye katılması; vergilemede planlama yapmayı, hukuki güvenliği artırmayı ve uyum maliyetlerini azaltmayı sağlamaktadır (BMF, 2013: 16).

Tablo 3. BMF 2013-2014 Yılları Arası Vergi Denetimine ilişkin Bilgiler

\begin{tabular}{|l|r|r|}
\hline Değer & \multicolumn{1}{|c|}{$\mathbf{2 0 1 3}$} & \multicolumn{1}{c|}{$\mathbf{2 0 1 4}$} \\
\hline Vergi Gelirleri & 70,8 Milyar $€$ & 78,5 Milyar $€$ \\
\hline Denetim Personeli Sayısı (Toplam) & 7.202 & 7.396 \\
\hline Büyük Mükelleflerin Denetimi (KDV) & 3.290 & 3.133 \\
\hline Ek Vergi Tarhiyatı & 690 Milyon $€$ & 847 Milyon $€$ \\
\hline Büyük Mükelleflerin Denetimi (Diğer) & 828 & 1.088 \\
\hline Ek Vergi Tarhiyatı & 6,8 Milyon $€$ & 3,1 Milyon $€$ \\
\hline Vergi Soruşturması & 136 & 150 \\
\hline Ek Vergi Tarhiyatı & 27,5 Milyon $€$ & 7,1 Milyon $€$ \\
\hline Vergi Ofislerindeki Inceleme SayıSı & 42.074 & 38.936 \\
\hline Ek Vergi Tarhiyatı & 146 Milyon $€$ & 182 Milyon $€$ \\
\hline Vergi Ofislerindeki Denetim (KDV) & - & 26.656 \\
\hline Vergi Ofislerindeki KDV İçin Ek Vergi Tarhiyatı & 643 Milyon $€$ & 549 Milyon $€$ \\
\hline
\end{tabular}

Kaynak: BMF, Facts and Figures 2013-2014 verilerinden tarafımızca oluşturulmuştur.

\subsection{Amerika İç Gelir İdaresi'nde (IRS) Denetimde Risk Analizi Uygulaması}

IRS, ilk kez mükelleflerin bildirimde gösterdikleri uyumu ölçmek için,1964 yılında uyguladığı Mükellef Uyumu Ölçüm Programı'nı (Taxpayer Compliance Measurement Program - TCMP) 1988 yılına kadar devam ettirmiştir. 2002 yılında ise geçmişte başarıyla uygulanan TCMP'ninyeni bir versiyonu olarak Ulusal Araştırma Programı (National Research Program - NRP) kullanılmaya başlanmıştır (Torrey, 2008: 3-5). Amerika'da ödenmesi gereken vergi ile ödenen arasındaki vergi açığı çeşitli yollarla tespit edilmektedir. IRS bu açığın en aza indirilmesinden sorumlu olarak, her yıl daha kapsamlı çalışmalar yürütmektedir. Bu açığı ölçmeye odaklanan NRP, sadece gelir vergisine yönelik değil, tüm vergi mükelleflerini ve tüm vergi türlerini içeren kapsamlı ve uzun vadeli bir ölçüm stratejisini benimsemiştir. NRP'nin bildirim faaliyetlerindeki tutarlılığı ölçmesinden sonra, IRS vergi uyumunu artırmak ve hizmet kalitesini yükseltmek için, bu hesaplamaları etkili şekilde kullanmaya başlamıştır (OECD, 2008: 24-25).

IRS tarafından kullanılan denetim yöntemlerinden biri de Ayırt Edici Envanter Fonksiyon Sistemi (Discriminant Inventory FunctionSystem - DIF)'dir. 1969 yılından itibaren uygulanan bu sistemde; mükellefler tarafından verilen her beyanname bilgisayar programı aracılığıyla incelenmekte, beyan edilen gelir ve harcamaların doğruluğu denetlenmekte ve çıkan sonuçlara bir puan verilmektedir. Puan ne kadar 
yüksekse, beyan edilenle gerçekte beyan edilmesi gereken değer arasında o kadar çok farklılık olduğu kabul edilmektedir. Bu sebeple yüksek puanlı beyannameler denetim için seçilmektedir (Karyağdı, 2006: 57).1980'lerden itibaren uygulanan, üçüncü kişilerden alınan bilgilerle veri eşleştirme sayesinde denetim süreci daha da iyileştirilmiştir (Torrey, 2008: 3). Geçmişte, sadece verilen beyannamelerin içerdiği bilgiler için yapılan DIF denetimi, 2002 yılından itibaren değişmiştir. Bu tarihten sonra uygulanan Beyan Edilmemiş Geliri Ayırt Edici Endeks Formülü (Unreported Income Discriminant Index Formula UI-DIF), olası beyanname dışı bırakılmış olan geliri tespit etmeye yönelmiştir. Verilen her beyanname hem bir DIF, hem de UI-DIF puanına sahip olmaktadır. Örneğin 2013 yılında küçük işletmeler ve kendi işinde çalışanların verdiği yaklaşık 1,5 milyon beyanname DIF aracılığıyla ayrıştırılmış; bunlardan 151.836 tanesi incelenmiş ve bunların 77.446 tanesi denetime sevk edilmiştir. Aynı dönemde NRP'de ise 144,9 milyon beyanname ayrıştırılmış, 14.687 tanesi incelenmiş ve bunlardan 13.449 tanesi denetim için seçilmiştir (US Goverment Accountability Office - GAO, 2015: 13).DIF puanının oluşturulmasında kullanılan kriterler, mükellefler tarafından Bilgi Özgürlüğü Yasası aracılığıyla öğrenilmeye çalışılmasına rağmen, günümüzde IRS bunları sır olarak saklamaya devam etmektedir (Karyağdı, 2006: 57-58).ABD'de 2014 yılı için en riskli 5 alan; transfer fiyatlandırması dışındaki diğer vergiden kaçınma yolları, KDV dışındaki diğer vergi hileleri, kaçakçılık/yasal olmayan aktiviteler, ödenmeyen vergi borçları ve doldurulmayan beyannameler olarak belirlenmiştir (OECD, 2015: 130).

Tablo 4. IRS 1995-2015 Yılları Arası Vergi Denetimine İlişkin Bilgiler

\begin{tabular}{|c|c|c|c|c|c|}
\hline Değer & 1995 & 2000 & 2005 & 2010 & 2015 \\
\hline $\begin{array}{l}\text { Beyanname } \\
\text { Sayısı }\end{array}$ & 154.293 .700 & 165.771 .300 & 174.364 .531 & 187.124 .450 & 191.857 .005 \\
\hline $\begin{array}{l}\text { Toplam Vergi } \\
\text { Geliri }\end{array}$ & 1,4 Trilyon \$ & 2,1 Trilyon \$ & 2,2 Trilyon $\$$ & 2,3 Trilyon $\$$ & 3,2 Trilyon \$ \\
\hline $\begin{array}{l}\text { Denetlenen } \\
\text { beyanlar } \\
\text { toplamı }\end{array}$ & 2.100 .144 & 715.915 & 1.328 .712 & 1.735 .083 & 1.373 .788 \\
\hline $\begin{array}{l}\text { Denetlenme } \\
\text { Oranı }\end{array}$ & $\% 1.4$ & $\% 0.4$ & $\% 0.8$ & $\% 0,9$ & $\% 0,7$ \\
\hline $\begin{array}{l}\text { Değişiklik } \\
\text { olmayan } \\
\text { beyanname } \\
\text { oranı }\end{array}$ & $\% 9$ & - & $\% 6$ & $\% 5$ & $\% 4$ \\
\hline Ek Vergi Tarhı & 27,9 Milyar \$ & 15,9 Milyar \$ & 48,6 Milyar \$ & 44,8 Milyar \$ & 25,1 Milyar \$ \\
\hline Ceza & 15 Milyar \$ & 15 Milyar \$ & 8 Milyar $\$$ & 28 Milyar $\$$ & 24 Milyar \$ \\
\hline $\begin{array}{l}\text { Suç } \\
\text { soruşturması }\end{array}$ & 5.000 & 3.372 & 4.269 & 4.706 & 4.486 \\
\hline $\begin{array}{l}\text { Denetim } \\
\text { Personeli* }\end{array}$ & 29.502 & 20.832 & 18.265 & 20.510 & 23.213 \\
\hline $\begin{array}{l}\text { Soruşturma } \\
\text { Personeli** }\end{array}$ & 3.363 & 2.746 & 2.823 & 2.751 & 2.318 \\
\hline
\end{tabular}

* Denetime yetkili; revenue agent, tax examiner (tax auditor) ve revenue officer statüsünde çalışanların toplam rakamıdır.

**Vergi suçlarını araştırmaya yetkili special agent statüsünde çalışanların toplam rakamıdır.

Kaynak: IRS Data Book raporlarındaki ilgili yılların verilerinden yararlanılarak tarafımızca oluşturulmuştur. 
Tablo 4, Amerika'da 1995-2000 yılları arasında vergi ve denetimine ilişkin bilgileri içermektedir. Tabloya göre beyanname veren mükellef sayısı ve vergi gelirleri yıllar itibariyle artış göstermiştir. Bununla birlikte mükelleflerin denetlenme oranlarının düştüğü görülmektedir. Risk analizinde amaç, riskli mükellefleri tespit etmek olduğundan, denetimlerin sayısal olarak az ama etkin olması amaçlanmaktadır. Bunun sağlanmasında, tarhı önerilen ek vergi ve cezaların artması bir göstergedir. Aynı zamanda IRS, denetimde etkinliğin belirlenmesinde önemli bir veri olarak gösterilen, denetlenen mükelleflerden beyanında değişiklik gerektirmeyenlerin oranını açıklamaktadır. Buna göre denetlenen toplam mükelleflerin 1995 yılında \% 9'unun beyanında değişiklik olmazken, 2015'te bu oran \% 4'e düşmüştür. Bu düşüş risk analiziyle birlikte mükellef seçiminde bir etkinlik sağlandığının ve gün geçtikçe daha isabetli denetimler yapıldığının bir göstergesidir.

IRS gerçekleştirdiği bu merkezi denetimi, eyaletlerden aldığı bilgilerle desteklemektedir. Özellikle, eyaletlerin verilen beyannamelerden topladığı bilgiler, eyaletler ile yapılan bilgi değişim anlaşmaları çerçevesinde aylık, üç aylık veya yıllık olarak Veri Değişim Programı (Data Exchange Program) aracılığıyla IRS ile paylaşılmaktadır. Eyaletler de IRS'den mükelleflerle ilgili bireysel dosyalardaki, uluslararası kazançla ilgili tutulan bazı bilgileri, mükellefin başka adresleri, eksik beyanlar ve farklı dökümler gibi bilgileri edinebilir. Günümüzde 40 eyalet, bireysel gelir vergisi mükellefleri için IRS ile karşılıklı bilgi eşleştirme programına kayıtlıdır (Birskyte, 2012: 175).Bu şekilde sağlanan bilgilerle eyalet düzeyinde vergi denetimleri de yapılabilmektedir. Fakat eyaletler, IRS'in ülke genelinde yaptığı etkin denetim ve diğer zorlayıcı önlemler sonucunda, kendi sınırları içinde yeni ek gelir tarhiyatı yaptıkları ve bundan gelir elde ettikleri için, bağımsız denetimlere az başvurabilir ya da denetimi hiç gerçekleştirmeyebilirler(Bkz. Birskyte, 2012: 182-183).

ABD'de IRS tarafından yürütülen ve büyük mükelleflerle işbirlikçi uyum modeli olan Uyum Güvence Süreci (Compliance Assurance Process - CAP) 2005 yılında pilot aşamayla başlamış, 2012'den itibaren ise sürekli uygulamaya konulmuştur (OECD, 2013a: 26). Programa katılan mükellefler her yıl beyannamelerini vermeden önce, potansiyel vergi sorunlarını tanımlamak ve çözmek için IRS ekibi ile işbirliği içinde çalışmaktadırlar. IRS, CAP programını yeni iki uygulamayla geliştirmektedir. Bunlardan ilki CAP programına girmek için geçilmesi gereken aşamaları belirleyen bir ön-CAP aşaması ve diğeri ise daha az karmaşık sorunları olan ve IRS ile işbirliği kurmak isteyen mükellefler için CAP bakım programıdır (Bkz. https://www.irs.gov/Businesses/ Corporations/Compliance-Assurance-Process).

\section{Türkiye'de Vergi Denetiminde Risk Analizine Yönelik Gelişmeler}

Türkiye'de gelir idaresinde bilgisayar destekli sistemlerin kullanımı VEDOP (Vergi Dairesi Otomasyon Projesi) ile 1998 yılında başlamıştır. 2004 yılında "Vergi Idaresinin Kapasitesinin Geliştirilmesi" projesiyle temelleri atılan riske dayalı denetim stratejisi ise hızlı bir şekilde gelişim göstermiştir. Bu tarihten önce Hesap Uzmanları Kurulu bünyesinde dar kapsamlı da olsa bazı çalışmalar yürütülmüştür. Örneğin kurul bünyesinde; İstihbarat, AR-GE ve Risk Analiz Merkezi kurulmuş ve burada muhtelif 
kaynaklardan toplanan veriler değerlendirilerek, ciro ve FAVÖK (faiz, amortisman ve vergi öncesi kar) rakamları ile diğer bazı özel kriterler göz önünde bulundurularak, sürekli gözetim ve denetim altında olacak "Hedef Mükellef Grubu" ve bu grubun her yıl revize edilmesiyle "Incelenecek Mükellefler Listesi" oluşturulmuştur (Arslan, Biniş, 2016: 457).

Vergi İdaresinin Kapasitesinin Geliştirilmesi Projesi, katılım öncesi mali yardım olarak adlandırılan Avrupa Birliği destekli twinning (eşleştirme) projelerinden birisidir (Ceylan, Tunalı, 2011: 130). Yapılan vergi incelemelerinin parasal verimliliğinin artırılmasını amaçlayan proje, 28 Kasım 2005'te başlamış; Türkiye'de Gelir İdaresi Başkanlığı (GIB) ve Hesap Uzmanları Kurulu ile Almanya ve İngiltere ortaklı olarak yürütülmüştür. Bu kapsamda Uyum Analizi ve Değerlendirme Müdürlüğü (Daha sonra Denetim ve Uyum Yönetimi Daire Başkanlığı olarak yapılanmıştır)oluşturulmuş ve burada merkezi risk analizinde kullanılacak yazılım kurulmuştur. Analizlerin yapılabilmesi için yazılımın tanıtımı, $A B$ uzmanları tarafından verilen uygulamalı yazılım eğitimleri ve risk modelinin açıklanması, 2007 yılında gerçekleşmiştir (GiB, 2008: 121). Bu tarihte tamamlanan proje; risk analizi, vergi mükellefi seçimi ve bilgisayarlı denetim tekniklerinin etkin kullanımını desteklemeyi ve bilgisayara dayalı kapsamlı istihbarat ve bilgilendirme sisteminin yürütülmesini sağlamayı amaçlamaktadır. Geliştirilen bilgisayar destekli denetim altyapısı, mükelleflerle ilgili verilere hızlı ve güvenilir şekilde ulaşmayı ve bunları denetim için kullanmayı içermektedir (Ceylan, Tunalı, 2011: 130).

2004'te uygulanmaya başlanan VEDOP-2 ile kayıt dışı ekonominin kayıt altına alınması için merkezde kurulan sistemlerle bilgisayarlı denetime başlanmış, Vergi İstihbarat Merkezi ile bankalardan ve diğer üçüncü kişilerden gelen bilgilerle mükellef beyanlarının 2005'te kurulan VERIA (Veri Ambarı) sisteminde karşılaştırılabilmesi sağlanmıştır (Gerçek vd., 2013: 71).Denetim ve Uyum Yönetimi Daire Başkanlığı bünyesinde kurulan Risk Analizi Merkezi, vergi denetim ve incelemelerinin bilgisayar destekli, etkin ve verimli olarak gerçekleştirilmesini sağlamak üzere faaliyetler göstermiştir. Bu tarihten sonra VERIA'dan gelen bilgiler doğrultusunda; Motorlu Taşıtlar Sürücü Kursu Projesi, Potansiyel Mükellef Projesi, Muhtasar ve Gelir Vergisi Beyanlarının Çapraz Analizi Projesi, Serbest Meslek Erbabı Beyan Analizi Projesi, Konut Kredili Gayrimenkul Satışları Projesi, Sahte Belge Kullananların Tespiti Projesi, Ba-Bs Form Analizine Dayalı 2006 B-101 Projesi, Tapu Bilgilerinin Analizi projesi, Kredi Kartı ile Yapılan (POS) Satışları İzleme Projesi, Kontör ve Altın Ticareti Yapan Mükellefler Projesi gerçekleştirilmiştir (GiB, 2009: 104-107; GiB, 2010: 81-86).Tedarikçi ve alt tedarikçilerin denetlenmesini sağlayan, böylece sahte faturaların tespit edilmesi olasılığını artıran en önemli uygulamalardan biri de karşıt inceleme imkanı veren $\mathrm{Ba}-\mathrm{Bs}$ formları aracılığıyla sağlanmıştır (Doğan, 2011: 75-76).

2010 yılında pilot proje olarak uygulanan Merkezi Risk Analizi ve Katmanlaştırma Modeli (MERAK), işlemlerin etkinliğinin ve mükelleflerin vergiye uyumunun artırılması ile incelenecek mükelleflerin; nesnel, risk analizlerine dayalı olarak seçilmesini amaçlamaktadır. Modelde toplam 859.993 mükellef kapsama alınmış ve bu mükelleflerin bölgeler ve/veya sektörler itibariyle ayrışması ve bu sayede mükelleflerin belirlenen veriler çerçevesinde büyüklüklerine göre katmanlaştırıp bu katmanlara göre risk analizine tabi tutulması planlanmıştır. Mükellefler öncelikle, 
sektörel ve/veya bölgesel düzeyde gruplara ayrılmıştır. Bundan sonra ise; mükelleflerin bilanço, gelir tablosu, beyanname ve e-VDO verileri ile üçüncü taraf bilgileri esas alınarak büyüklükleri belirlenmiş ve buna göre katmanlara ayrılmaları sağlanmıştır. Böylece, ilgili sektör ve/veya bölgesel düzeyde mükellefler en büyük/büyük/orta/küçük katmanlara göre, her biri kendi sınıfında analize tabi tutulmuş ve bütünüyle matematiksel ve istatistiki yöntemler veya hesaplamalarla her mükellefe bir risk puanı atanmıştır. Bu risk puanına göre mükellefler, vergi incelemesine alınıp alınmayacakları açısından değerlendirmeye tabi tutulmuştur (GiB, 2011: 10).Yine 2010 yılında uygulanan KDV İadesi Risk Analiz Sistemi (KDViRA),iade işlemlerinin bütün aşamalarının idare tarafından takip ve kontrol edilebilmesini kolaylaştırmıştır. Sahte Belge Risk Analizi Programı ile sahte belge düzenleme riski yüksek olan mükellefler ortaya çıkarılarak, hem KDVIRA sisteminin, hem de sahte belge düzenleme incelemelerinin desteklenmesi sağlanmıştır. KDVIRA sistemi ile Vergi Denetmenleri Otomasyon Sistemi (VEDOS) arasında kurulan entegrasyon sayesinde de riskli bulunan mükellefler doğrudan taşradaki personele bildirilerek incelemeye alınmaya başlanmıştır (GiB, 2011: 49).

Vergi Denetim Kurulu'nun (VDK) kurulmasıyla 2011 yılından itibaren, GiB tarafından vergi incelemesi ile risk analizi faaliyeti kapsamında yürütülen bazı projeler Kurul'a devredilmiştir. Günümüzde hala GiB tarafından, temelde kayıtdışı ekonomiyle mücadele için uygulanan risk analizine dayalı projeler; Vergisel Uyum Analiz Modeli ve Mükellef Değerlendirme Sistemi, Veri Erişim ve Görsel Analiz Sistemi (VEGAS), KDV Iadesi Risk Analizi (KDViRA) Sistemi, KDV İadesi Makro Analiz Raporu (MAR), Sahte Belge Risk Analiz Programı (SARP), Elektronik ÖTV Takip Sistemi olarak sıralanır. Bu projelere yönelik bazı veriler ise şöyledir (Bkz. GiB, 2016):2015 yılında KDVIRA'da risk analizi sonrası mükelleflerin düzeltme beyannamesi ile indirdikleri iade tutarı 957 milyon, sorunlu mükelleflerin matrah artışı ise 6 milyar 218 milyondur. Aynı dönemde SARP'ta7.399 mükellef sahte belge düzenleme riski yüksek olması nedeniyle VDK'ya bildirilmiştir. GiB, 2014 Aralık'tan itibaren Mükellef Karne Sistemi ile sicil, beyanname, ödeme ve performans olmak üzere4 farklı kategoride 160 farklı kriterle uyum bozukluklarını anlık olarak ölçerek, her bir mükellef için "Genel Uyum Seviyesi" belirlenmektedir. Uyum seviyesi yüksek olan mükelleflere birtakım teşvik ve kolaylıklar sağlanması diğer taraftan uyum seviyesi daha düşük olan mükelleflere ise bilinçlendirme ve gönüllü uyuma yönlendirme çalışmaları yapılması planlanmaktadır. Bu çalışma ile uyumlu mükelleflerin, vergi idaresine bakışını olumlu yönde değiştirmesi ve vergi idaresinin etkinliğinin arttırılması öngörülmektedir.

VDK'nın görev ve yetkileri içinde "her türlü bilgi, veri ve istatistiği toplamak suretiyle oluşturulacak Risk Analiz Sistemi üzerinden mükelleflerin faaliyetlerini gruplar ve sektörler itibarıla analiz etmek, mukayeseler yapmak ve bu suretle risk alanlarını tespit etmek" yer alır. VDK tarafından yapılacak vergi incelemeleri; esas olarak sektör, konu ve mükellefler itibarıyla; Kurul bünyesinde kurulan Risk Analiz Merkezinde (VDKRAMER), mevcut ve yeni geliştirilen programlar kullanılarak yapılan analiz ve mukayeseler neticesinde belirlenmektedir (VDK, 2016: 15).Kurul bünyesinde 2014 yılı sonu itibariyle oluşturulan Merkezi Elektronik Risk Analiz ve Mükellef Seçim Programı (VDK-MERAM)ile her türlü bilgi, veri ve istatistik kullanılarak mükelleflerin faaliyetleri; gruplar ve sektörler itibarıyla analiz edilmekte, mukayeseler yapılmakta ve bu suretle risk alanları tespit edilmektedir. Bu tarihten itibaren risk unsurları belirlenerek, Risk 
Analiz Modeli oluşturulmuş ve belirlenen risk unsurlarının mükellefler nezdinde tespiti amacıyla yazılım çalışmaları 2015 yılı içinde tamamlanmıştır. Risk Analiz Programının geliştirilmesi amacıyla VDK'nın genel işleyişi gözden geçirilerek, sistemin yenilenmesi ve en uygun kaynak ve zaman kullanımını sağlamaya yönelik çalışmalar yürütülmüştür. Programda, Mali İstihbarat Modülü oluşturulmuş; ihbarlar, görüş öneri raporları, incelemenin genişletilmesi talepleri, araştırma geliştirme raporları, projeler, eylem planları, diğer kamu kurumlardan gelen her türlü yazı ve yürütülen medya takip çalışmaları mükellefler ile ilişkilendirilmeye başlanmıştır. Analiz ve kontrolleri tamamlanan incelemelerin VDK-MERAM üzerinden gönderilmesi sağlanmıştır(VDK, 2016: 29-30).

VDK-RAMER' de yapılan analizler sonucu belirlenen ve hakkında inceleme oluru alınan mükelleflerin, Grup Başkanlıklarına sevki, Bilgi İşletim Sistemi (VDK-Bis) aracılığıyla yapılmaktadır. Denetim ve inceleme faaliyetlerinde kullanılmak ve vergi müfettişlerine rehberlik sağlamak amacıyla riskli mükellefler hakkında yürütülen analiz çalışmalarına ilişkin, mükelleflerin beyan özetlerini de içeren "Risk Durum Raporları" oluşturulmuştur. Haklarında inceleme başlatılan mükelleflerin tamamı için durum raporları, incelemenin VDK-RAMER'den gönderilip gönderilmediğine bakılmaksızın görevli vergi müfettişine VDK-BiS (Bilgi İşletim Sistemi) üzerinden elektronik ortamda sunulmaya başlanmıştır. Ayrıca Türkiye Geneli Risk Durum Raporunun hazırlanması için çalışmalar yürütülmektedir(VDK, 2016: 30).

Risk analiz programına Sahte Belge Risk Analiz Modülü (SABE-RAM) eklenmiştir. Bu sistemle, sahte belge düzenleme ve kullanma fiillerine etkin bir şekilde zamanında mücadele edilebilmesi için, özellikle cari dönemde faaliyet gösteren sahte belge düzenleyicilerinin ve kullanıcılarının tespit edilmesi amaçlanmıştır. Türkiye'nin vergisel risk durumunu gösterir haritanın oluşturulması amacıyla, Türkiye Risk Haritası Modülü oluşturulmuştur. Modül ile risk konuları, bölge ve sektörler, mükellef büyüklügü, mükellefiyet türü, inceleme durumları vb. birçok değişken gözetilerek her bir dönem için ihtiyaca yönelik çok sayıda elektronik harita anlık olarak hazırlanabilmektedir(VDK, 2016: 31).Ayrıca VDK, sahte belge düzenleyenlerin tespiti ve risk analiz çalışmalarının uyumlaştırılması amacıyla GiB ile çalışmalar yürütmektedir. Gazi Üniversitesi ile Risk Analiz Programı VDK-MERAM'ın akademik ve bilimsel açıdan testi amacıyla iş birliği çalışmalarına 2015'te başlamıştır(VDK, 2016: 32).Denetim alanında bilişim teknolojilerinde görülen bu gelişmeler ülkemizde denetim standartlarını yükselterek, denetimin etkinliğini artırmaktadır (Çetin, 2010: 85).

2015 yılında risk analizi sistemiyle tespit edilen 26.972 mükellef incelemeye sevk edilmiştir. Modelin geliştirilmesi çalışmaları neticesinde 6.318 mükellef analizlere tabi tutulmuştur. Analiz çalışmalarında 49.432 risk unsuru değerlendirilmiş ve37.335 risk unsuru mükellefler nezdinde riskli bulunmuş ve inceleme çalışmalarında kullanılmak üzere raporlanmıştır (VDK, 2016: 64). Aşağıda yer alan Şekil 4, 2007 yılından 2015 yılına kadar risk analizine dayalı toplam vergi incelemelerinin (toplam proje sonuçları), vergi incelemeleri toplamına olan oranını göstermektedir. 2007 yılında GiB bünyesinde 176 mükellefin incelemesiyle başlayan projeler hem sayısal hem de çeşit olarak artış göstermiştir. VDK'nın kurulmasıyla birlikte denetimlerin büyük bir bölümü risk analizine odaklanmaya başlamıştır. Başlangıçta vergi incelemelerinin binde 
1 oranında risk analizine dayandığı görülürken, 2015 yılında 26.972 vergi incelemesiyle risk analizlerinin toplamdaki payı \%46'ya yükselmiştir.

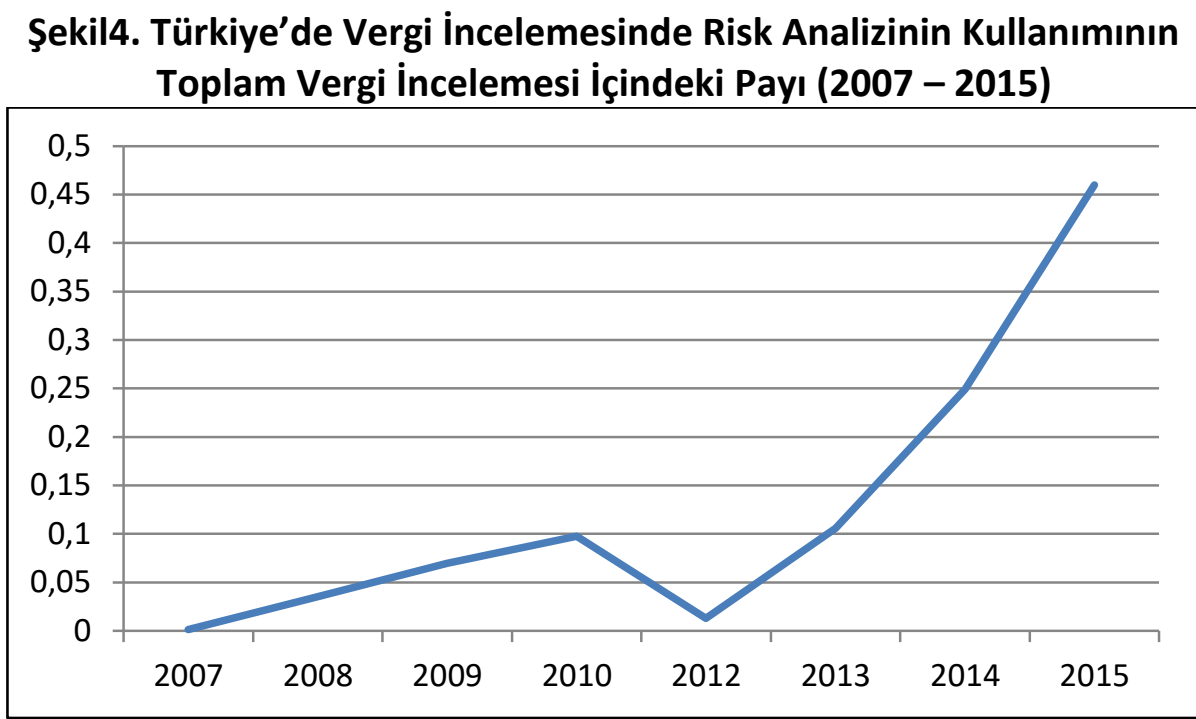

Kaynak: GiB ve VDK Faaliyet Raporları (2011 yılına ilişkin veriye ulaşılamamıştır.)

RAMER'den gönderilen denetimlerin dışında VDK; ihbar ve şikayetler neticesinde; teftiş, soruşturma, inceleme ve denetimler sırasında yapılan tespitlere istinaden; kamu kurum ve kuruluşlarından intikal eden ve doğrudan veya dolaylı olarak vergisel konuları içeren inceleme ve denetim raporları ile inceleme talepleri sonucunda ve vergi müfettişleri tarafından riskli olduğu düşünülen sektörlere yönelik düzenlenen görüş ve öneri raporları uyarınca incelemeler yapmaktadır.

Vergi incelemesi içinde riske dayalı olanların artan payı ile incelemenin etkinliği arasındaki ilişkiyi ölçmek için, risk analizine geçiş sonrası ve öncesi dönemi birlikte değerlendirmek gerekir. Fakat Gelirler Genel Müdürlüğü (GGM), GiB ve VDK'nın verilerinin birbirleriyle eşleştirilmesi ve sağlıklı bir analiz yapılması güçtür. Bu durum hem kurumların geçiş sürecinde denetimle ilgili toplu verileri açıklama güçlügünden, hem de ilgili kurumların uzun süredir açıkladıkları bazı verileri değiştirmelerinden veya yeni veriler açıklamalarından kaynaklanmaktadır. Örneğin; 2010 yılında Vergi İnceleme ve Denetim Koordinasyon Kurulu'nun oluşturulma kararı, daha sonra 2011 yılında VDK'nın kurulması ile vergi incelemesine ilişkin veriler sağıklı bir şekilde tutulamamıştır. Ayrıca vergi incelemesinin etkinliğini karşılaştırma açısından; incelenen mükellef sayısı, tarhı istenen ek vergi, aktif denetim elemanı sayısı gibi verilerin açıklanması son yıllara özgüdür. Bu sebeple denetimde etkinlik açısından yapılacak bir değerlendirme geniş kapsamlı olmayacaktır. Yine de aşağıdaki Tablo 5 yardımıyla bazı değerlendirmeler yapabiliriz. 
Tablo 5. Türkiye'de 2001-2015 Arası Vergi İncelemesine İlişkin Bilgiler

\begin{tabular}{|c|c|c|c|c|c|c|c|c|c|c|}
\hline Değer & 2001 & 2003 & 2005 & 2007 & 2009 & 2011 & 2012 & 2013 & 2014 & 2015 \\
\hline Toplam Vergi Gelirleri (I & 39.73 & 84.31 & 119.25 & 171.09 & 196.31 & 284.49 & 317.21 & 367.51 & 401.68 & 464.88 \\
\hline & 5 & 6 & 0 & 8 & 3 & 0 & 8 & 7 & 3 & \\
\hline Vergi & 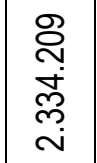 & 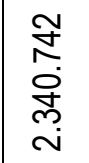 & 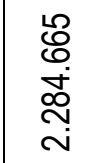 & 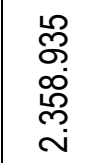 & 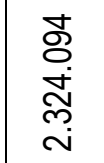 & $\begin{array}{l}\bar{N} \\
\text { No} \\
\text { ల్ల } \\
\stackrel{N}{ }\end{array}$ & 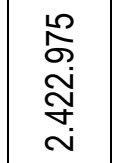 & 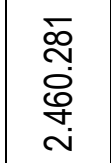 & 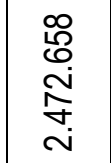 & 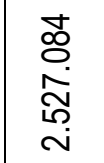 \\
\hline & 68.28 & 68.25 & 104.57 & 135.84 & & & 124.50 & 163.36 & 149.04 & 159.5 \\
\hline & 6 & 1 & 8 & 7 & & & 7 & 7 & 7 & 0 \\
\hline İncelenen M & $\begin{array}{c}34.14 \\
3\end{array}$ & $\begin{array}{c}34.12 \\
5\end{array}$ & 41.83 & 45.282 & 47.787 & 16.267 & 46.845 & 71.352 & 55.284 & 58.67 \\
\hline & 1,46 & 1,46 & 1,83 & 1,92 & 2,06 & 0,69 & 1,93 & 2,90 & 2,24 & 2,32 \\
\hline Ian Matrah Farkı (Milyon & $\begin{array}{c}13.47 \\
8\end{array}$ & $\begin{array}{c}18.83 \\
5 \\
\end{array}$ & 38.715 & 30.451 & 97.972 & - & $\begin{array}{c}131.00 \\
1\end{array}$ & 53.675 & 39.37 & 46.75 \\
\hline $\begin{array}{l}\text { Tarhı İstenen Ek Vergi (Milyon } \\
\text { TL) }\end{array}$ & - & - & - & - & 7.532 & 3.926 & 4.536 & 8.561 & 7.939 & 9.804 \\
\hline Mükellef Başına Düşen Ek & & & & & 157.61 & 241.34 & 96.830 & 119.98 & 143.61 & 167.0 \\
\hline & & & & & 6 & 8 & & $\frac{7}{250}$ & 0 & 7 \\
\hline Mükellef Başına Düşen Ceza & - & - & - & - & - & - & - & 6 & 2 & 6 \\
\hline
\end{tabular}

*Gelir ve kurumlar vergisi toplamından oluşmaktadır.

**2009 yılına kadar açıklanmayan bu veri için tahminleme yapılmıştır.

Kaynak: GGM, GiB ve VDK faaliyet raporlarındaki verilerden yararlanılarak tarafımızca oluşturulmuştur.

Tablo 5 incelendiğinde, gelir ve kurumlar vergisi toplam mükellef sayısının yıllar itibariyle çok fazla değişmediği görülmektedir. İncelenen mükellef sayısının artış gösterdiği ve buna bağlı olarak da toplam düzenlenen rapor sayısının 2 katından daha fazla arttığı tespit edilmektedir. Kişi başına düşen denetim oranı da artmıştır. Bu oran birçok ülke ortalamasının üzerindedir. Denetimlerin sayısal olarak artışından ziyade, riskli mükelleflerin tespit edilmesi ve denetimlerin bunlara yoğunlaşması önem taşımaktadır. Bu sebeple denetim birimleri faaliyet raporlarında 2008'den itibaren açıklanmaya başlanan vergi incelemesi sonucunda tarhı istenen vergi, önemli bir göstergedir. Bu tutarın artışı, denetimlerin etkinliğinin arttığını göstermektedir. Ayrıca incelenen mükellef başına düşen tarhı istenen vergi ve kesilen ceza tutarı da artmıştır.

\section{Sonuç ve Öneriler}

Mükelleflerin vergi uyumunu artırmak, uyumsuz mükelleflerin ise bu davranışlarını tespit etmek vergi idaresi için kolay değildir. Vergi idaresinin bunu yaparken kullandığı araçlardan biri olan vergi denetimi, uzun yıllardır bilgisayar sistemleri aracılığıyla riskli mükellefleri tespit etmeye yönelmiştir. Vergi denetimi süreci genellikle; gelir idarelerinin mükelleflerle en çok karşııklı etkileşime geçtiği alandır. Bu süreçte, mükelleflerin kendilerini güvende hissetmeleri ve idarenin doğru şeyi yaptığına olan inançlarını kaybetmemeleri gerekmektedir. Bunu sağlamak ise vergi denetim sürecine, idare tarafından yapılan rutin işlemlerden daha çok özen göstermeyi gerektirir. Bu özeni göstermek; her aşamada standartları sağlamayı ve etkinliği 
artırmayı gerekli kılar. Sistemler idare tarafından sürekli yenilenirken, teknolojik gelişmelerden de destek alınmaktadır.

Amerika'da bilgisayar kullanımına dayalı teknolojik altyapının önce olması sebebiyle, kullanımı daha eski olduğu görülen riske dayalı denetim, günümüzde vergi idarelerinin önemli bir aracı haline gelmiştir. Vergi idarelerinin mükellef odaklı yapılanmasından sonra vergi denetimi, vergi uyumunu artırmayı önceliğine alarak “vergi uyum modeli” üzerine yoğunlaşmıştır. OECD’nin önerdiği, Avusturalya'da da uygulanan vergi uyum modeli, vergisel ödevlerini zamanında yerine getiren mükelleflere karşı mümkün olduğunca esnek ve yardımcı olma, bunun tersi olarak uyumsuz mükelleflere ise oldukça sert yaptırımlar uygulama sürecidir. Uyum gösteren mükelleflere sağlanan kolaylıklar, denetim sürecinin daha başarılı olmasını sağlamıştır. Özellikle, büyük mükelleflerle işbirlikçi uyum modeli, işlemlerinde karşılaşabilecekleri vergi riski daha fazla olan bu mükelleflere, idareyle birebir danışma yoluyla kendi vergi riski yönetimi politikalarını uygulamaları konusunda destek sağlayarak; sorunlarının hızlı çözümünü temin etmekte, bu durum ise idareye güven ve hukuki belirliliği artırmaktadır.

Türkiye'de 2004 yılında bir projeyle, 2007 yılında ise aktif olarak başlayan denetimde risk analizi, GiB tarafından geliştirilerek devam etmiştir. GiB'in günümüzde de uyguladığı projeler; kayıt dışı ekonominin önlenmesiyle birlikte, vergi uyumunu artırma amacı taşımaktadır. Özellikle, uygulanan Vergisel Uyum Analiz Modeli ve Mükellef Değerlendirme Sistemi mükelleflerin uyum bozukluklarını ölçme açısından önemlidir. 2011 yılında kurulan ve denetim faaliyetlerini risk analiz sistemi üzerinden yürütmekle sorumlu olan VDK' da, sahip olduğu yazılım altyapısıyla görevlerini etkin şekilde gerçekleştirmektedir. 2015 yılında denetlenen mükellef başına düşen tarhı istenen vergi ve kesilmesi önerilen ceza toplamının artması, sistemin başarısının bir göstergesi olarak kabul edilebilir. Bununla birlikte ülkemizde, çalışmada incelenen diğer ülkelerde uygulandığı tespit edilmiş ve önemli olduğu düşünülen bazı eksiklikler söz konusudur. Bu eksikliklerin giderilmesi, denetimde etkinliğin ve vergi uyumunun artması ile denetim sonuçlarının karşılaştırılabilirliğinin sağlanması için aşağıdaki düzenlemeler yapılmalıdır:

- Faaliyet raporlarında aynı verilerin yayınlanmasına, denetimde etkinliğin ölçülmesi için veri standartlaştırılmasına özen gösterilmeli ve daha önce açıklanmayan, denetlenen mükelleflerden matrah farkı tespit edilmeyenlerin oranı, vergi açığı tahminleri gibi veriler açıklanmalı.

- Birebir risk analizinde esas alınan kriterler ve senaryolar olmasa bile, genel olarak risk alanları açıklanmalı ve mükelleflere riskli alanlarda kendilerini kontrol etme imkanı tanınmalı.

- Vergi riski en fazla olarak kabul edilen büyük mükelleflerle, işbirlikçi uyum modeli kurulmalı, böylece onların gönüllü uyumu artırılmalı.

- Şirketlerde vergi riski yönetimi teşvik edilmeli.

- Risk analizi sonucunda yapılan değerlendirmeler belirli periyodlarla kamuoyuna duyurulmalı, mükelleflere risk analizinin tanıtımı yapılmalı ve bu konuda bilinçlenmeleri sağlanmalı. 


\section{Kaynakça}

Akbey, F. (2014). "Türkiye'de Vergi Denetimi ve Gelirleri Üzerine Bir İnceleme”, Dokuz Eylül Üniversitesi Iktisadi ve Idari Bilimler Fakültesi Dergisi, C. 29 (1), ss. 63-103.

Arslan, M. \& Biniş, M.(2016). "Vergi Denetiminde Bir Etkinlik Sorunu Olarak Mükellef Seçimi", 29. Türkiye Maliye Sempozyumu Tebliğler Kitabı, Sakarya Beşiz Yayınları, ss. 443-462.

ATO. (2013). Compliance in Focus 2013-2014, Canberra, https://www.ato.gov.au/ uploadedFiles/Content/CS_C/downloads/CSC35735NAT74689.pdf, (17.01.2015).

Australian Government Inspector-General of Taxation (IGT). (2013). Review in to Aspect of the Australian Taxation Office's use of Compliance Risk Assessment Tools, 2013, http://igt.gov.au/files/2014/12/use-of-risk-assessment-tools.pdf,

Baurer, Lewis I. (2005). "Tax Administrations and Small and Medium Enterprises (SMEs) in Developing Countries", Worldbank Publication, http://wwwwds.worldbank.org/external/default/WDSContentServer/WDSP/IB/2007/03/20 /000020439_20070320154946/Rendered/PDF/391100Taxadmin01PUBLIC1.pdf , (30.11.2015).

Benk, S. \& Kartalcı, K. (2015). “Gelir İdarelerinde Risk Yönetimi: OECD Risk Yönetim Modeline Yönelik Bir Değerlendirme", Ekonomik ve Sosyal Araştırmalar Dergisi, C. 11(1), ss. 43-59.

Birskyte, L. (2012). "Fostering Inter-Organisational Relationships As A Way To Increase Efficiency In Tax Administration", Intellectual Economics, 6, 2(14), ss. 174-188.

BMF (Austrian Federal Ministry of Finance). (2013). Annual Report 2013 of the Austrian Tax and Customs Administration, Vienna, https://english.bmf.gv.at/services/ BMF-BRAnnual_Report_Tax_Customs_2013.pdf?4vfpu8, (17.11.2015).

BMF. (2013). Facts and Figures 2013 - 2014, https://english.bmf.gv.at/services/ publications/publications.html, (25.04.2016).

Ceylan, M. A. \& Tunalı, A. (2011). "Bilişim Sistemleri Denetimi ve Gelir İdaresi Başkanlığı'nın Bilişim Sistemleri Alanında Yaptığı Çalışmalar”, Dış Denetim Dergisi, Temmuz-Ağustos-Eylül, ss. 123-136.

Crandal, W. (2010). Revenue Administration: Performance Measurement in Tax Administration, IMF Technical Notes and Manuals, https://www.imf.org/ external/pubs/ ft/tnm/2010/tnm1011.pdf, (25.04.2016).

Çetin, G. (2010). "Bilişim Teknolojilerindeki Gelişmelerin Vergilemede Kayıt Düzeni ve Denetim Uygulamalarına Etkisi", Ekonomi Bilimleri Dergisi, C. 2 (1), ss. 79-86.

Doğan, U. (2011). “Data Warehouse and Data-Mining Tools for Risk Management: The Case of Turkey", Risk-Based Tax Audits: Approaches and Country Experiences, 
Ed. Munawer Sultan Khwaja, Rajul Awasthi, Jan Loeprick, Washington DC, The World Bank Publishing, ss. 71-76.

Dökmen, G. \& Günel, T. "Vergi Uyumunun Sağlanmasında Duyarlı Regülasyon Sistemi: Avusturalya Örneği", Ekonomik ve Sosyal Araştırmalar Dergisi, Özel Sayı, C.8 (8), ss. 43-65.

Enden, Eelcovan der, Jos de Groot, Ericvan der Stroom, (2010). "Netherlands", Tax Risk Management From Risk to Opportunity, Ed. Anuschka B. \& Sander K. Netherlands, IBFD, ss. 327-350.

European Commission (EC). (2006). Risk Management Guide For Tax Administrations, Fiscalis Risk Analysis Project Group, http://ec.europa.eu/taxation_customs /resources/documents/taxation/tax_cooperation/gen_overview/risk_manage ment_guide_for_tax_administrations_en.pdf, (17.10.2015).

Freedman, J. (2010), "Tax Risk Management and Corporate Taxpayers - International Tax Administration Developments", Tax Risk Management From Risk to Opportunity, Ed. Anuschka, B.\& Sander, K., Netherlands, IBFD, ss. 111-133.

Freedman, J. \& Geoffrey Loomer, J. V. (2009). “Corporate Tax Risk and Tax Avoidance: New Approaches", British Tax Review, (1), ss. 74-116.

Fritz, J. (2010). "The Use of Information forthe Purpose of Selecting Taxpayers at Risk: State of the Art of the Case Selection Procedure in Austria", Tax Tribune, 26.

Gerçek A., Demirbaş, T., Yüce, M., Giray, F. \& Oğuzlar, A. (2013). Türk Gelir Idaresinde E-Devlet Uygulamalarının Mükellefler Tarafından Benimsenmesini Etkileyen Faktörlerin incelenmesi, İstanbul, Bilgesam Yayınları.

GiB. (2008). Faaliyet Raporu 2007, http://www.gib.gov.tr/sites/default/files/fileadmin/ user_upload/yayinlar/2007_Faaliyet_Raporu.pdf, (14.01.2016).

GiB. (2009). Faaliyet Raporu 2008, http://www.gib.gov.tr/sites/default/files/fileadmin/ faaliyetraporlari/2008/faaliyetraporu2008.pdf, (15.01.2016).

GiB. (2010). Faaliyet Raporu 2009, http://www.gib.gov.tr/fileadmin/faaliyetraporlari/ 2009/2009_faaliyet_raporu.pdf, (15.01.2016).

GiB. (2011). Faaliyet Raporu 2010, http://www.gib.gov.tr/fileadmin/faaliyetraporlari/ 2010/Faaliyet_raporu_2010.pdf, (15.01.2016).

GiB. (2016). Faaliyet Raporu 2015, http://www.gib.gov.tr/sites/default/files/ fileadmin/faaliyetraporlari/2015/2015_faaliyet_raporu.pdf, (27.04.2016).

Gill, Jit B. S., (2003). "The Nuts and Bolts of Revenue Administration Reform", http://siteresources.worldbank.org/INTTPA/Resources/NutsBolts.pdf, (20.10.2015),

Hainey, M. (2011). "Building and Integrating Databases for Risk Profiles in the United Kingdom", Risk-Based Tax Audits: Approaches and Country Experiences, Ed. Munawer S. K. \& Rajul Awasthi, J. L. Washington DC, The World Bank Publishing, ss. 65-70. 
Henehan, P.J. \& Walsh, A. (2008). Global Tax Risk Management, Bloomsbury Professional, UK.

HMRC. (2015). Annual Report and Account 2014 - 15, https://www.gov.uk/ government/uploads/system/uploads/attachment_data/file/449343/HMRC_An nual_Report_and_Accounts_2014-15_Web_accessible_version_.pdf, (26.04.2016).

HMRC. Number of Taxpayers and Registered Traders, https://www.gov.uk/ government/uploads/system/uploads/attachment_data/file/519575/Apr16_Nu mbertaxpayerstraders_bulletin_Final.pdf, (25.04.2016).

HMRC. Tax \& NIC Receipts, https://www.gov.uk/government/uploads/system/ uploads/attachment_data/file/517448/Mar16_Receipts_NS_Bulletin_final.pdf, (25.04.2016).

IRS. Data Book. (1995, 2000, 2005, 2010, 2015). https://www.irs.gov/pub/irs-soi/15 databk.pdf, https://www.irs.gov/pub/irs-soi/10databk.pdf, https://www.irs.gov/ pub/irs-soi/05databk.pdf, https://www.irs.gov/pub/irs-soi/00databk.pdf, https://www.irs.gov/pub/irs-soi/95dbfullar.pdf, (25.04.2016).

Karyağdı, N. (2006). Amerika Birleşik Devletlerinde Gelir Idaresi'nde Vergi Incelemesi, Ankara, Maliye Bakanlığı Strateji Geliştirme Başkanlığı Yayını.

Khwaja, M. S. (2011). "Overview", Risk-Based Tax Audits: Approaches and Country Experiences, Ed. Munawer S. K. \& Rajul Awasthi, J. L., Washington DC, The World Bank Publishing, ss. 1-10.

Loeprick, J. \& Engelschalk, M. (2011). "Simplified Risk Scoring for SMEs", Risk-Based Tax Audits: Approaches and Country Experiences, Ed. Munawer S. K. \& Rajul Awasthi, J. L., Washington DC, The World Bank Publishing, ss. 45-54.

OECD. (1997). "Risk Management - Practice Note", http://www.oecd.org/tax/ administration /1908440.pdf, (13.12.2015).

OECD. (2004a). "Compliance Risk Management: Managing and Improving Tax Compliance", http://www.oecd.org/site/ctpfta/37212610.pdf, (15.12.2015).

OECD. (2004b). "Compliance Risk Management: Audit Case Selection Systems", http://www.oecd.org/tax/administration/33818568.pdf, (15.12.2015).

OECD. (2006). "Strengthening Tax Audit Capabilities: General Principles and Approaches", https://www.oecd.org/tax/administration/37589900.pdf, (25.04.2016).

OECD. (2008). "Monitoring Taxpayers' Compliance: A Practical Guide Based on Revenue Body Experience", http://www.oecd.org/tax/administration/ 40947920.pdf, (15.12.2015).

OECD. (2009). "Compliance Management of Large Business Task Group, http://www.oecd.org/australia/43241144.pdf, (15.12.2015). 
OECD. (2013a). “Co-operative Compliance: A Framework: From Enhanced Relationship to Co-operative Compliance", http://dx.doi.org/10.1787/9789264200852-en, (18.01.2015).

OECD. (2013b). "Tax Administration 2013: Comparative Information on OECD and other Advanced and Emerging Economies", http://www.oecd.org/tax/ administration/tax-administration-series.htm, (15.12.2015).

OECD. (2015). "Tax Administration 2015: Comparative Information on OECD and other Advanced and Emerging Economies", http://www.oecd.org/ctp/administration/ tax-administration-23077727.htm, (15.12.2015).

Russo, R. (2010). "Risk Management in Taxation", Risk Management and Corporate Governance: Interconnections in Law, Accounting and Tax, Ed. Marjinvan, D. \& Elst, C. UK, Edward Elgar Publishing, , ss.163-190.

Schmölders, G. (1976). Genel Vergi Teorisi, Çev. Salih Turhan, İstanbul, İstanbul Üniversitesi Yayınları.

Tekin, F. \& Çelikkaya, A. (2016). Vergi Denetimi, 7. Baskı, Ankara, Seçkin Yayıncılık.

Torrey, A. (2008). "The Discriminant Analysis Used by the IRS to Predict Profitable Individual Tax Return Audits", http://digitalcommons.bryant.edu/cgi/ viewcontent.cgi?article=1000\&context=honors_mathematics, $(10.01 .2016)$.

Turhan, S. (1993). Vergi Teorisi ve Politikası, İstanbul, Filiz Kitabevi.

US Government Accountability Office (GAO). (2015). IRS Return Selection: Certain Internal Controls of Audits the Small Business and Self-Employed Division Should Be Strengthened, http://www.gao.gov/assets/680/674228.pdf, (22.04.2016).

VDK. (2016). Faaliyet Raporu 2015, http://www.vdk.gov.tr/File/?path=ROOT\%2f Documents\%2fDosya\%2fFaaliyetRaporu_2015.pdf, (27.04.2016).

Vellutini, C. (2011a). "Key Principles of Risk-Based Audits", Risk-Based Tax Audits: Approaches and Country Experiences, Ed. Munawer, S. K. \& Rajul Awasthi, J. L. Washington DC, The World Bank Publishing, ss.13-22

Vellutini, C. (2011b). "Risk-BasedAudits: AssessingtheRisks", Risk-Based Tax Audits: Approaches and Country Experiences, Ed. Munawer S. K. \& Rajul Awasthi, J. L. Washington DC, The World Bank Publishing, ss. 23-36.

Whait, R. (2012). “Developing Risk Management Strategies in Tax Administration: The Evoluation of The Australian Tax Office's Compliance Model", EJournal of Tax Research, 10(2), ss. 436-464.

Wunder, H. F. (2009). "Tax Risk Management and the Multinational Enterprise", Journal of International Accounting, Auditing and Taxation, 18, ss. 14-28. 
